\title{
Landslide dams in Central Asia region
}

\author{
Alexander STROM ${ }^{\text {a)* }}$
}

\begin{abstract}
The Central Asia region has been a scene of numerous large-scale bedrock landslides that have blocked river valleys producing landslide-dammed lakes, more than 100 of which still store water. The largest one is the Usoi dam $2.2 \mathrm{~km}^{3}$ in volume and more than $550 \mathrm{~m}$ high in Pamirs (Tajikistan) that originated in 1911 due to strong (M7.2) earthquake. It forms the $500 \mathrm{~m}$ deep Sarez Lake - the world deepest natural reservoir that poses a threat to Central Asian countries located downstream in the Pianj - Amu Daria River basin. Though many of landslide-dammed lakes should be considered as stable and safe features, catastrophic outburst floods that occurred in $20^{\text {th }}$ Century, emphasize high potential hazard of such natural blockages. Several prehistoric landslidedammed lakes in Pamirs and Tien Shan with intact dams were filled by lacustrine sediments, but most of natural dams were breached and deeply eroded providing excellent opportunity to study their internal structure and grain-size composition - parameters determining dams' short-term and long-term stability at a large extent. Additional factors, increasing or decreasing rockslide dams stability are exemplified by case studies from the Central Asia region.
\end{abstract}

Key words : landslide dam, rockslide, outburst flood, Pamirs, Tien Shan

\section{Introduction}

The Central Asia region extends from the Caspian Sea in the west to western part of China in the east and from Kazakh plain in the north to the northern faces of Hindu Kush and Karakorum in the south. Its large portion is occupied by the Pamirs and Tien Shan mountain systems (Fig. 1), which highest peaks rise above 7000 m.a.s.l. These mountains are the sources of most of Central Asia rivers, which, being fed by glaciers, snowmelt water and rains have incised valleys up to $2-3 \mathrm{~km}$ deep. Such extreme topography along with complex geological structure, active tectonics and high seismicity form background favorable for largescale slope failures.

Numerous bedrock landslides (rockslides) have occurred in Pamirs and Tien Shan producing hazardous natural phenomena such as long runout rock avalanches and dammed lakes, more than 100 of which still store water. Much more frequent landslides in loose unconsolidated Quaternary deposits and Mesozoic and Cenozoic sediments typical of the foothill areas rarely create permanent dams, since, usually, they are smaller and their bodies, even if they block river channel, are eroded much faster.

This paper presents a brief overview of the existing and past landslide dams in Pamirs and Tien Shan. Most examples described hereafter, are from Kyrgyzstan and Tajikistan; some case studies are from Southern Kazakhstan, Afghanistan, Uzbekistan, and Xinjiang in Western China.

Though many of the existing landslide-dammed lakes should be considered as stable and safe features, catastrophic outburst floods that occurred in $20^{\text {th }}$ Century, some of which are described hereafter, empha-

* corresponding autho

a) Institute of Geospheres Dynamics of Russian Academy of Sciences, Leninsky Avenue, 119334 Moscow, Russia size high potential hazard of natural blockages. One of the potentially hazardous objects is the Usoi dam 2.2 $\mathrm{km}^{3}$ in volume and more than $550 \mathrm{~m}$ high in Pamirs (Tajikistan) that originated in 1911 due to strong (M 7.2) earthquake. The $500 \mathrm{~m}$ deep Sarez Lake that has been impounded upstream is the world deepest landslide-dammed lake (Costa \& Schuster, 1991). Longterm stability assessment of this dam and lake that pose a potential threat for the communities living in the Bartang, Pianj and Amu-Daria River valleys in Tajikistan, Afghanistan, Uzbekistan and Turkmenistan with the population over 5.5 million people (Gaziev, 1984, UNISDR, 2000, Schuster, 2002), as well of some other similar dams requires better knowledge of their internal structure and composition that can be achieved, in particular, by detail study of those natural dams, which were breached and deeply eroded providing excellent opportunity to learn more about their interiors. Their characteristic features are discussed briefly hereafter.

\section{Existing landslide-dammed lakes}

Many fascinating mountainous lakes are known in the Central Asian region. Largest of them, like Issyk Kul in Kyrgyzsran, Kara Kul in Tajikistan or Bagrash Kul in China ('Kul' means lake in Turkic languages) fill intermountain neotectonic depressions; hundreds of small lakes at the topmost parts of ranges are glacial. There are, however, numerous lakes, both small and large, that originated due to river damming by bedrock landslides. Among them are the Usoi (No. 1) and the Yashilkul (No. 2) lakes in the Tajik and the Shiva Lake (No.4) in the Afghan part of the Pamirs, the Iskanderkul Lake (No. 8) in the Southen Tien Shan (Tajikistan), the Sarychelek (No. 7), the Karasu (No. 5), the Kulun (No. 17), the Kiolsu (No. 26) Lakes in the Central Tien Shan (Kyrgyzstan), the Bolshoe 
Almaty (No. 24) and the Kiol (No. 27) Lakes in Southern Kazakhstan, the Badak Lake in Uzbekistan (No. 25), the Tianchi (No. 9) and the Big Dragon (No. 10) Lakes in the Chinese Tien Shan (numbers here and hereafter are the same as on Fig. 1). These natural reservoirs, many of which are famous tourist sites along of their beauty, store large amount of sweet water that can be used for irrigation and electricity production. Some of them, at the same time, pose a significant threat for the communities living downstream.

\section{1 Rockslide-dammed lakes in Pamirs, Tajikistan}

The Pamirs ("Roof of the World") is the highest mountain system of the Central Asia region. Its topmost summits-the Kongur (7719 m), the Kongurtiube (7595 m), the Mustag-Ata $(7546 \mathrm{~m}$ ) (all in the eastern, Chinese part of the Pamirs) and the Ismail Somoni (former Kommunism) peak $(7495 \mathrm{~m}$ ) in the Tajik part. Western and Eastern Pamirs are characterized by extremely rugged terrain with up to $3 \mathrm{~km}$ deep valleys, while its central part forms a Tibet-like plateau with wide flat valleys at 3000-4000 m.a.s.l. divided by 1-1.5 $\mathrm{km}$ high ranges. Case studies described hereafter are from the Western Pamirs (see Fig. 1-A).

\subsubsection{Usoi Dam and Sarez Lake (No. 1)}

This world largest historical non-volcanic landslide (Costa \& Schuster, 1991) originated on February 18, 1911, when M7.2 earthquake caused catastrophic wedge-like failure of about $2.2 \mathrm{~km}^{3}$ ( $\sim 6$ billion tons) of quartzite, schist, shale and dolomite and formation of the $567 \mathrm{~m}$ high Usoi natural dam (Photo 1) named af- ter the small village that was buried with 54 inhabitants. The $5 \mathrm{~km}$ long (across the valley) and $3.75 \mathrm{~km}$ wide dam blocks the Murgab River valley at $38^{\circ} 16.5^{\prime}$ N, $72^{\circ} 36^{\prime}$ E. Despite the remoteness and inaccessibility of the site, Russian researchers performed first studies of this unique feature soon after the event (Shpilko, 1915, Preobrajensky, 1920). Its regular studies started in 1960s (Scheko, Lekhatinov, 1970, http://sarez.ferghana.ru/).

The $500 \mathrm{~m}$ deep and $60 \mathrm{~km}$ long lake (Fig. 2) that has been impounded upstream contains almost $17 \mathrm{~km}^{3}$ of water. It was named after the submerged Sarez village. 3 years later, in 1914, seeping water found its way through the blockage (though source of those springs could be not the Sarez Lake itself, but either the small Shaddau Lake in the tributary valley dammed by the same landslide, or water from the glacier valleys that remain above the headscarp - see http : // sarez.ferghana.ru/). Significant filtration through the dam started about 1925. Estimates of the present-day mean discharge passing through the dam range from 45.8 to $47 \mathrm{~m}^{3}$ / (UN International Strategy for Disaster Reduction, 2000). During the flood periods when water rises for about $5 \mathrm{~m}$ above the mean annual level, it increases up to $85 \mathrm{~m}^{3} / \mathrm{s}$ (UN International Strategy for Disaster Reduction, 2000). The critically important fact is that seepage through the dam takes place through the uppermost $\sim 140 \mathrm{~m}$ of the dam only (most permeable zones are within the uppermost 50$70 \mathrm{~m}$ of the blockage), while remaining $350-400 \mathrm{~m}$ are

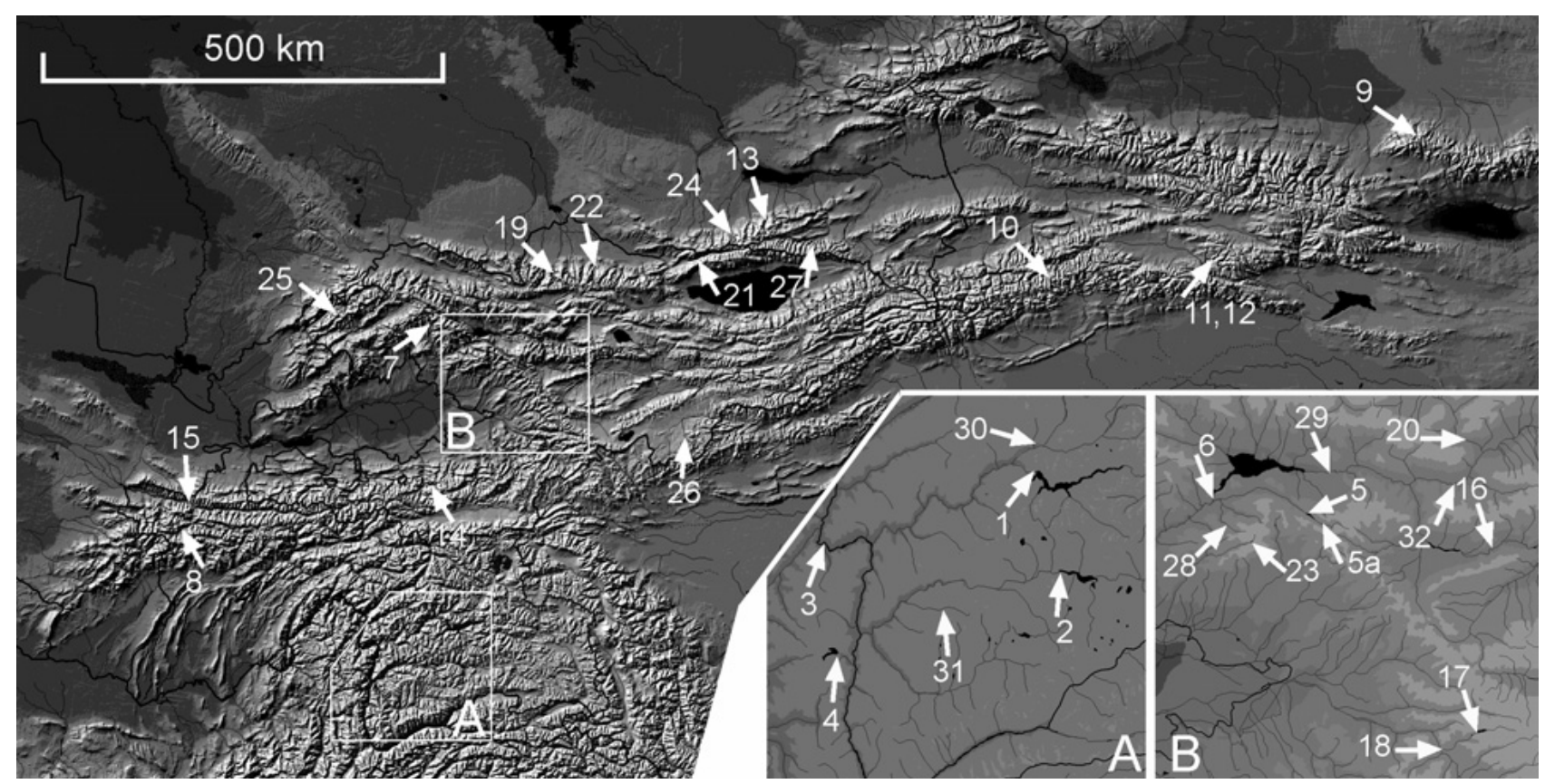

Fig. 1 Location of landslide dams in the Central Asia region mentioned in this paper (numbered arrows). A and B-zoomed parts of Western Pamirs and Central Tien Shan. 1-Usoi ; 2-Yashilkul ; 3 -Shids ; 4-Shiva ; 5 Karasu ; 5a-Kapkatash ; 6-Karakul ; 7 - Sarychelek ; 8-Iskanderkul ; 9-Tianchi ; 10-Big Dragon ; 11-Twin-Lakes (Upper) ; 12-Twin-Lakes (Lower); 13Issyk ; 14-Yashinkul ; 15-Aini ; 16-Beshkiol ; 17-Kulun ; 18-Kulun Mouth ; 19-Aksu ; 20 -Kokomeren ; 21-Djashilkul ; 22-Arashan ; 23-Kutmankul ; 24-Bolshoe Almaty ; 25-Badak ; 26-Kiolsu ; 27 -Kiol ; 28 -Dead Lakes ; 29-Djuzumdybulak ; 30 -Kudara ; 31 -Rivakkul ; 32 - Ornok 
practically impermeable. Nature of such impermeability is debatable. Some researchers (Papyrin, 1990) believe that dams' lower part is composed of a gigantic, almost intact bedrock block. From my point of view, based on observations of numerous deeply dissected rockslides, the internal part of the Usoi dam is composed, most likely, of the intensively crumbled and densely compacted rock debris. This impermeable "core" is overlaid by angular boulders and large fractured blocks that form permeable carapace (Strom, 1994, 2006). Large rockslide dams featuring such internal structure will be described hereafter.

Seeping water forms powerful springs, which appear $\sim 140 \mathrm{~m}$ below the lake level in the canyon that cuts the downstream slope of the blockage (see Photo 1B). Its head erodes both the dams' body and sediments left by debris flows that originate from the glacier valleys remaining above the headscarp. In 1947 a rockfall from the headscarp wall blocked the channel and diverted these debris flows towards the lake (Paramonov, 1969).

Downstream slope of the blockage is crossed by bowshape scarps (see Photo 1B) that can be interpreted as headscarps of secondary landslide (Paramonov, 1969). Largest of them could originate when rapidly moving rockslide collided with the opposite bank of the Murgab River valley (Strom, 2010). It can be assumed that such secondary deformations have produced potential sliding surfaces, thus decreasing the overall stability of the dam.

According to regular observations, lake level increases gradually (up to $20 \mathrm{~cm} /$ year) and is now 3261 m.a.s.l., only $38 \mathrm{~m}$ below the lowermost part of the blockage (at maximal water level). Though studies performed since $60^{\text {th }}$ revealed that the dam in its present state should be considered as a stable feature that could not be destroyed by water pressure or immediate overtopping, its long-term (decades and centuries) perspective is questionable. It is hypothesized, in particular, that large-scale slope failure may occur on the lakes' right bank, $4-5 \mathrm{~km}$ from the blockage (Photo 2),

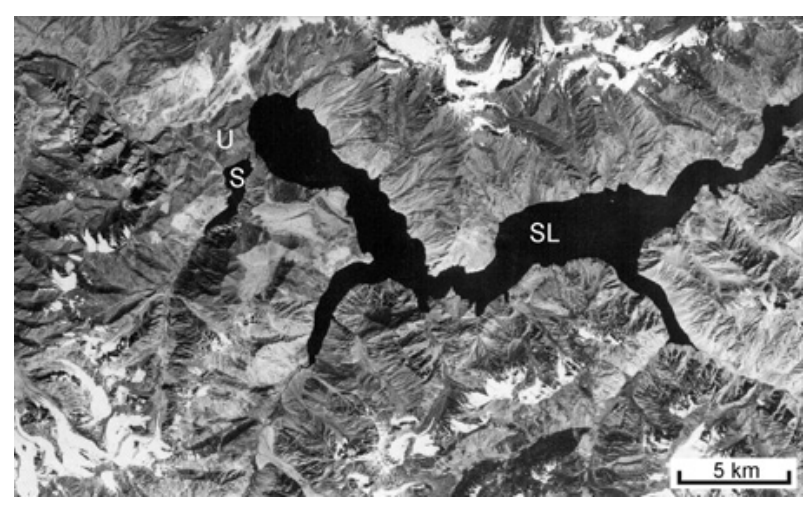

Fig. 2 Satellite imagery of the Sarez Lake. U-the Usoi Landslide, SL - the Sarez Lake, S - the Shaddau Lake which would cause the huge wave. The latter could gash over the dam at its lowermost section resulting in the dam's partial or complete breach (see Kazakov, http : //sarez.ferghana.ru/kazakov.html).

Different researchers estimated volume of this "Right-bank landslide" from 0.3 to $2.0 \mathrm{~km}^{3}$. However, possibility of such a large-scale failure, its volume and rate estimates are still controversial and require more studies (UNISDR, 2000, Ischuk, 2006). Additional uncertainty of this slope stability assessment is associated with Central Pamirs high seismic activity (9 points of the MSK-64 scale, according to the official seismic zoning map of Tajikistan). It should be mentioned that none of several gigantic past rockslides that had blocked the Murgab River valley close to the Usoi dam (Fedorenko, 1988) remain intact, proving that longterm dam stability can not be guaranteed without special security measures.

Recently, within the frames of the World Bank Project, the early warning system has been installed aimed to record various indicators of the dams' instability (seismic strong motion, rapid increase of water level, etc.) and to allow people living downstream to escape to special shelters arranged above the endangered level.

Nevertheless, since the potential risk of the blockage breach and of the devastating outburst flood exists, special measures should be undertaken to ensure longtem safety of the Lake Sarez regardless of any dynamic effects such as strong earthquake or impact of the surge wave caused by a large-scale lake bank failure.

\subsubsection{Yashilkul Dam and Lake (No. 2)}

The Yashilkul landslide-dammed lake is located at $37^{\circ} 47^{\prime} \mathrm{N}, 72^{\circ} 44^{\prime} \mathrm{E}, 3734$ m.a.s.l. Unlike the gigantic Usoi rockslide that formed rather compact and, thus, very high dam, the Yasilkul rockslide about $50 \times 10^{6} \mathrm{~m}^{3}$ in volume had converted into rock avalanche that filled the valley at a distance of about $4 \mathrm{~km}$ (Photo 3 ). The dam is characterized by dual structure with semirounded moraine-like bouldery material inside overlaid by carapace of angular gneiss blocks and debris. It was hypothesized that Yashilkul Lake had been first dammed by the end moraine, later on overtopped by a rockslide. I assume, however, that it is a pure rockslide dam. When about $1 \mathrm{~km}$ high slope collapsed, main part of rockslide composed of gneiss blocks and debris had pushed bouldery glacial deposits resting at the foot of the slope. This moraine material fell into river channel, blocked it and was overlaid by the following bedrock debris (Strom, 1994).

Rockslide had occurred before $13^{\text {th }}$ Century, since Arabian inscriptions of this age were found on some angular boulders on top of the dam. The lake, fed by the Alichur River, is the source of the Gunt River. Being nearly $20 \mathrm{~km}$ long and with an area of $36.1 \mathrm{~km}^{2}$, it 


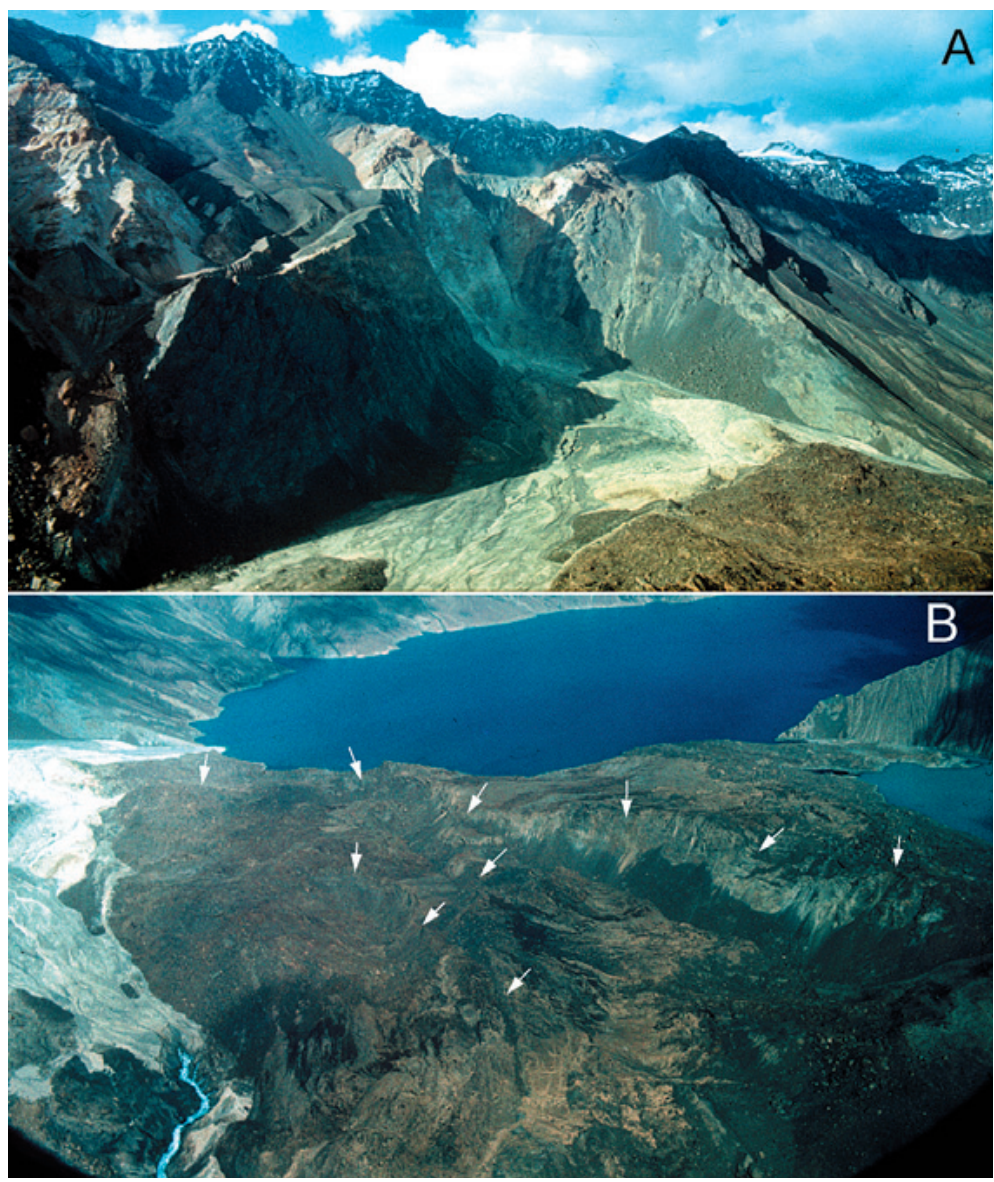

Photo 1

Helicopter views of the Usoi rockslide headscarp (A) and body (B). Notice that the downstream slope of the dam is deformed by high secondary scarps (marked by white arrows on Photo 2B). Blue water body at the right part of Photo $1 \mathrm{~B}-$ the Shaddau Lake. Seeping water erodes the canyon visible at the lower left part of Photo 1B

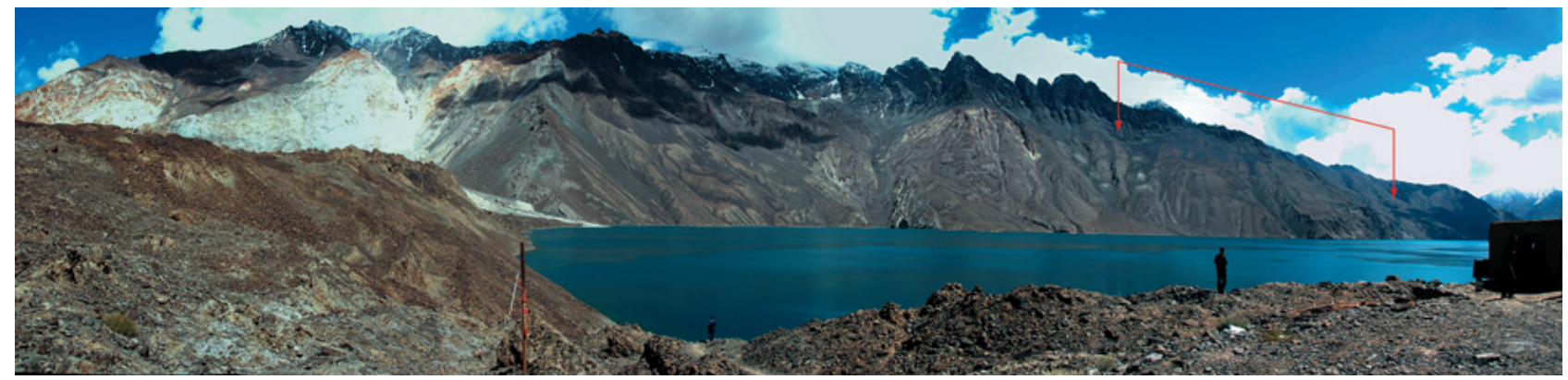

Photo 2 Location of the assumed "Right-bank landslide" (marked by red arrows) that can cause a surge wave in the Sarez Lake. Concave slope just right from the Usoi headscarp - the source zone of the giant Pleistocene Murgab rockslide, according to Fedorenko (1988)

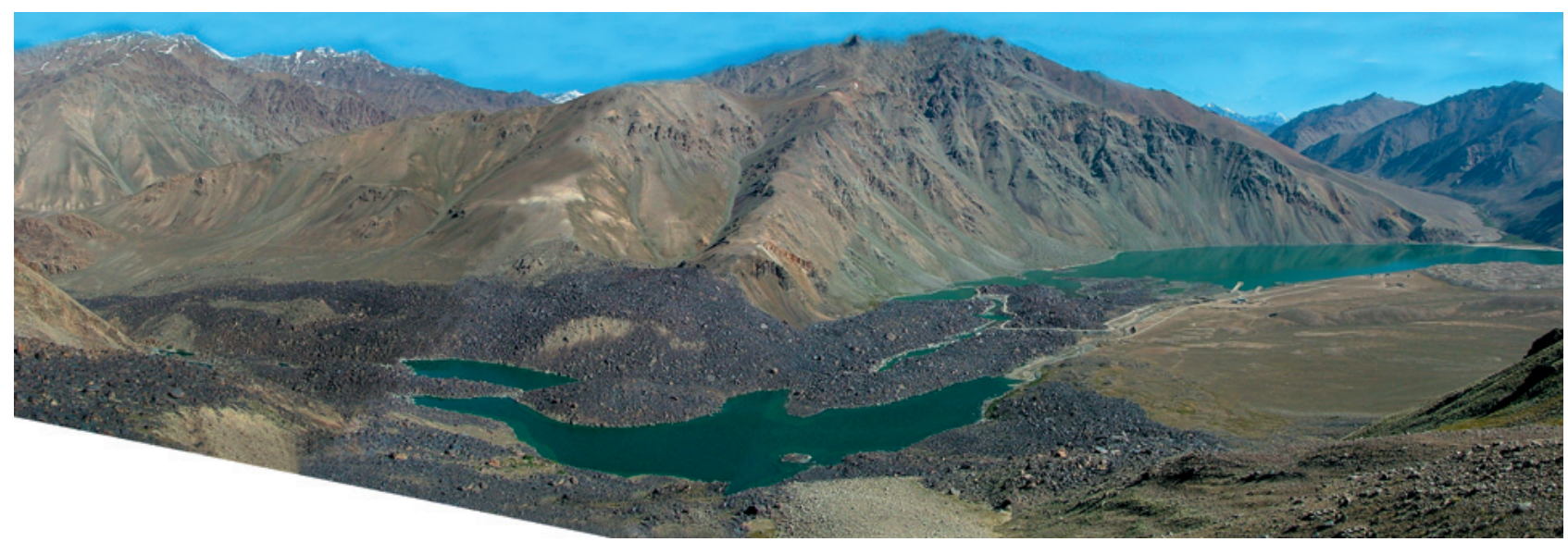

Photo 3 Overview of the Yashilkul rockslide dam. Photo courtesy N. Ischuk. (Photo was made before the spillway construction) 
is rather shallow-up to $50 \mathrm{~m}$ only and stores about 0.5 $\mathrm{km}^{3}$ of water. The dam is stable, moreover the outflow $\left(\sim 4 \mathrm{~m}^{3} / \mathrm{s}\right.$ as an annual mean value) passes through the coarse carapace composed of gneiss blocks. Recently it became artificially controlled by the spillway constructed across the dam's crest to increase power production of the hydraulic power plants at the lower part of the Gunt valley.

\subsubsection{Shids rockslide dam (Pamirs, Tajikistan- Afghanistan border) (No. 3)}

Several partially or completely eroded rockslide dams exceeding $1 \mathrm{~km}^{3}$ in volume each could be found in the Pianj River valley, along or close to the TajikAfghan border. One of them originated in the prehistoric times on the $\sim 1.5 \mathrm{~km}$ high right bank of the Pianj valley composed of Proterozoic granite and gneiss $\left(37^{\circ} 55.5^{\prime} \mathrm{N}, 71^{\circ} 18.5^{\prime} \mathrm{E}\right)$. Though this $400 \mathrm{~m}$ high rockslide body had been almost completely incised by powerful Pianj, 20-30 m high dam still exist at Shids village and remnant lake extends about $15 \mathrm{~km}$ upstream Pianj valley (Fig. 3).

Further upstream lacustrine sediments could be found along the banks of Pianj and Bartang Rivers up to $\sim 2000$ m.a.s.l., indicating maximal extent of lake sedimentation. Since small frontal part of rockslide body that remains on the left bank of the valley rises up to $\sim 2200$ m.a.s.l., it can be assumed that the effective dams' height (height of the lowermost point of the dams' crest, corresponding to the maximal possible lake level) was less than its maximal thickness, and did not exceed $300 \mathrm{~m}$ - about one half of that of the Usoi dam. It is evident that powerful Pianj with mean discharge of $467 \mathrm{~m}^{3} / \mathrm{s}$ (almost 10 times more than that of the Murgab River) (State Water Inventory) should inundate the lake in several years and that the dam

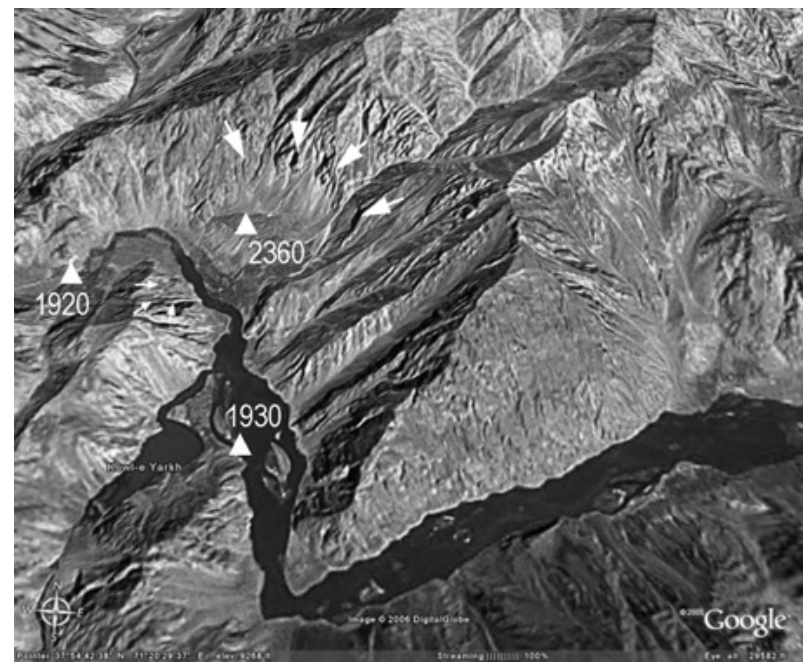

Fig. 3 Shids rockslide and remnant lake in the Piang River valley. Google Earth panoramic view. Large white arrows mark rockslide headscarp; small white arrows-frontal limit of the dam's body. Elevations of the marked points are above sea level was breached by overtopping, which is typical of blockages at affluent rivers. However, at some specific conditions, exemplified hereafter, landslide-dammed lakes even on large rivers can exist for centuries and millennia (Korup et al., 2006, Hewitt, 2006).

\section{2 Rockslide-dammed lakes in the Tien Shan}

The Tien Shan Mountains, though not as high as the Pamirs, have been affected by hundreds of large-scale bedrock landslides many of which caused rivers' damming. Unlike Western (Afghan and Tajik) and Eastern (Chinese) Pamirs, where up to $3 \mathrm{~km}$ deep gorges dividing main mountain chains have been formed by glacial and water erosion, many of the Tien Shan ranges represent individual neotectonic anticlines divided by wide intermountain neotectonic depressions, nowadays used by river valleys (Makarov, 1977, Chedia, 1988). Most of the Tien Shan river damming sites could be found either in narrow gorges eroded through the barriers between intermountain depressions by main streams with large (thousands of square kilometers) catchments and high discharges, or in the tributary valleys that cross slopes of separate anticline ridges. The latter have much smaller catchments (dozens or few hundreds square kilometers) and runoff. Extensive study of several existing and past landslide dams in Tajikistan and Kyrgyzstan was performed in $70^{\text {th }}-80^{\text {th }}$ (Fedorenko, 1988).

\subsubsection{Rockslide-dammed lakes in the Karasu-Left River valley}

The 150 m deep Karasu Lake (No. 5) was formed in the Karasu-Left River valley dammed by the rockslide $2.5 \times 10^{8} \mathrm{~m}^{3}$ in volume and about $250 \mathrm{~m}$ high, that caved from the $900 \mathrm{~m}$ high left bank of the valley composed of Paleozoic limestone. This dam is located at $41^{\circ} 34.5^{\prime} \mathrm{N}, 73^{\circ} 13.5^{\prime} \mathrm{E}$ exactly over the trace of the Talas-Fergana active fault - one of the largest faults of the entire Tien Shan Mountain system. Age of this blockage is not less than 1000 years (Belousov, et al., 1994). Such a long-term existence of the lake is due to the size of the dam and small discharge of the river. Lake's volume is about $0.22 \mathrm{~km}^{3}$ - almost the same as the dams' volume. Absence of the overtopping and erosion evidence indicates its present day stability. One more much smaller landslide-dammed lake - the Kapkatash one (No. 5a) is located $10 \mathrm{~km}$ upstream, also over the trace of the Talas-Fegana fault (Fig. 4). Though its exact age is unknown it can be hypothesized that both rockslides occurred simultaneously, being triggered by one of the last strong earthquake at this segment of the Talas-Fergana fault (Mamyrov, et al., 2009) .

\subsubsection{The Sarychelek Dam and Lake (No. 7)}

The 234-m deep landslide-dammed Sarychelek Lake is located in the upper reaches of the Karasu-Right River valley at $41^{\circ} 51.5^{\prime} \mathrm{N}, 71^{\circ} 59^{\prime} \mathrm{E}$. It was formed by 
giant prehistoric bedrock landslide about $34 \mathrm{~km}^{2}$ in size that had caved from the $6.5 \mathrm{~km}$ long headscarp in the Devonian sedimentary rocks (Fig. 5). Dams' volume ( $\sim 6 \mathrm{~km}^{3}$ if not more), more than one order bigger than the amount of water stored in the lake $(0.48$ $\mathrm{km}^{3}$ ), guarantees its long-term stability. Several smaller lakes are located just within the rockslide body and in the vicinity of the Sarychelek Lake; some of the latter could be dammed by landslides triggered by the M7.5 1946 Chatkal earthquake, which epicenter was close to this site.

\subsubsection{The Iskandrkul Dam and Lake (No. 8)}

The largest existing landslide-dammed water body in the south-western, Tajik part of the Tien Shan (the Alai and Gissar Ranges) is the Iskanderkul Lake located at $39^{\circ} 05.1^{\prime} \mathrm{N}, 68^{\circ} 22.9^{\prime} \mathrm{E}, 2195$ m.a.s.l. The 3.4 $\mathrm{km}^{2}$ and up to $72 \mathrm{~m}$ deep lake is the source of the Iskanderkul-Daria River. Rockslide occurred on the slope composed of Paleozoic sedimentary rocks. The Iskanderkul-Daria originates from the surficial outflow with $18.6 \mathrm{~m}^{3} / \mathrm{s}$ mean discharge. It erodes an up to 50 $70 \mathrm{~m}$ deep gorge in the landslide body with a powerful waterfall at its central part (Fig. 6). It indicates that the dam undergoes intensive backward erosion, which could, in time, result in its breach.

The rockslide nearly $1 \mathrm{~km}^{3}$ in volume that dams the Iskanderkul Lake is the largest one of bedrock landslide cluster located in this area. One more rockslide dam $\sim 160 \mathrm{~m}$ high that covers $1.5 \mathrm{~km}^{2}$ had blocked a

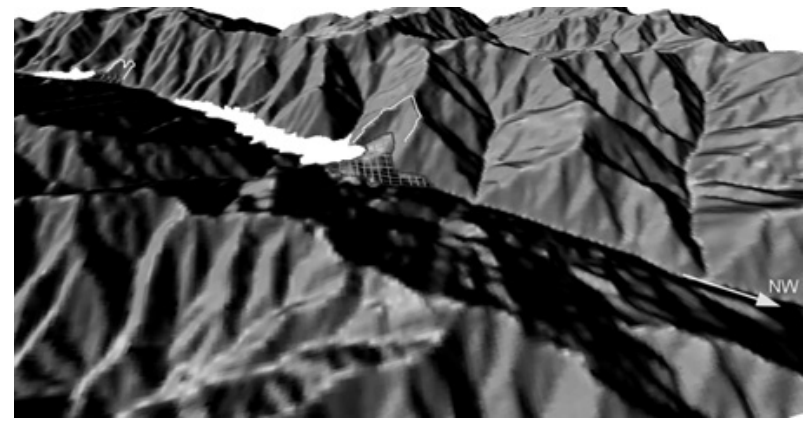

Fig. 4 The Karasu (the bigger one) and the Kapkatash rockslide dammed lakes at the Talas-Fergana fault zone. 3-D view composed from the 3" SRTM DEM. The TalasFergana fault passes along the Karasu-Left River valley. Distance between the dams is $\sim 10 \mathrm{~km}$ junction of two rivers that bring their water to the Iskanderkul Lake (see Fig. 6-C). Small lakes that had been formed in both blocked valleys had been partially filled by sediments and, finally, drained.

\subsubsection{Landslide-dammed lakes in the Chinese Tien Shan}

Largest landslide-dammed lakes in the eastern, Chinese part of the Tien Shan are the Tianchi Lake (No. $9,43^{\circ} 54^{\prime} \mathrm{N}, 88^{\circ} 07^{\prime} \mathrm{E}$ ) and the Big Dragon Lake (No. 10, $43^{\circ} 36.3^{\prime} \mathrm{N}, 82^{\circ} 23.5^{\prime} \mathrm{E}$ ). Both dams created by rockslides about $1.5-2.0 \mathrm{~km}^{3}$ in volume are nearly $400 \mathrm{~m}$ high. According to ${ }^{10} \mathrm{Be}$ cosmogenic dating the Tianchi Lake originated during the Late Glacial epoch, about 12 ka BP (Yi, et al., 2006).

These lakes are of the same type as the Sarychelek one (No. 7), being formed by gigantic rockslides in the short and steep valleys dissecting neotectonic anticline limbs. Enormous size of rockslides, surpassing lakes' volume, guarantees their stability.

One more interesting case study in the Chinese Tien Shan is located at $42^{\circ} 41^{\prime} \mathrm{N}, 84^{\circ} 56.8^{\prime}$ E. Here a rockslide that can be named as "Twin-lake" had caved just above junction of two river valleys and blocks both of them forming two lakes at 3025 and 2890 m.a.s.l. (No. 11 \& 12) (Fig. 7). The site could be considered as a favorable one for a pumping power plant, since most expensive structures of such scheme - upper and lower reservoirs had been "constructed" by Nature. Traces of temporary surficial overflow from both lakes are visible on the Google Earth satellite imagery.

\section{Outburst floods caused by landslide dams breach}

Most of the above-mentioned landslide-dammed lakes have existed for a long time - from about 100 years (the Sarez Lake) up to millennia or more. However, much more landslide dams in the study region have been breached either by overtopping or due to internal erosion. Several devastating outburst floods caused by rockslide dam breach had occurred in Central Asia in the $20^{\text {th }}$ Century (Pushkarenko, Nikitin, 1988).

\section{1 The 1963 Issyk Lake catastrophe}

On July 7, 1963 catastrophic outburst of the Issyk

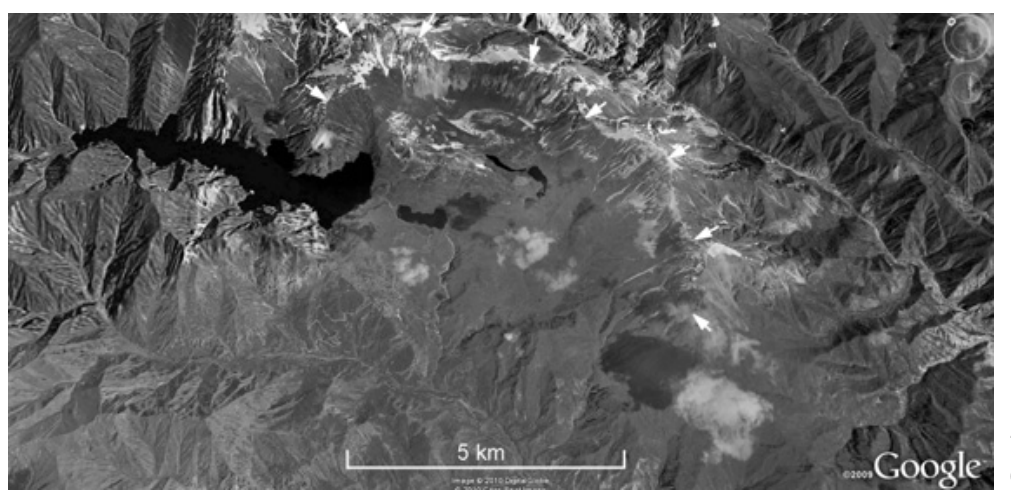

Fig. 5

The Sarychelek rockslide and rockslide dammed lake. Google Earth image. White arrows mark the headscarp 
Lake (No. 13) occurred east from the former capital of Kazarhstan, the Almaty city. It resulted in the devastating debris flow that passed through the Issyk valley and which traces are visible till now, almost 50 years after the disaster. The prehistoric landslide dam $\left(43^{\circ}\right.$ $15.3^{\prime} \mathrm{N}, 77^{\circ} 28.9^{\prime} \mathrm{E}$ ) about $0.6 \mathrm{~km}^{2}$ in size and up to $100 \mathrm{~m}$ high $\left(\sim 25 \times 10^{6} \mathrm{~m}^{3}\right.$ in volume $)$ was composed of diorite blocks (on top) and same rock crushed at a high extent in the dams' interior (Eugen Gaspirovich, personal communication). The dam was breached by overtopping caused by debris flow that originated in the upper reaches of the catchment due to outburst of the glacial lake. Up to 6-7 million $\mathrm{m}^{3}$ of debris was brought into the Issyk lake within 3-4 hours resulting in rapid increase of the lake level and creation of waves that hit the upper part of the blockage. They destroyed the dam's crest and water stored in the lake rushed downstream eroding the dam body as well as river banks (Gerasimov, 1965). Peak discharge recorded about $10 \mathrm{~km}$ downstream, close to the Issyk town, was $745 \mathrm{~m}^{3} / \mathrm{s}, 150$ times more than mean river discharge at this site $-4.96 \mathrm{~m}^{3} / \mathrm{s}$ (State Water Inventory). Only small remnant lake remained after the disaster. Later on an artificial dike was built at the eroded canyon to protect downstream valley and the Issyk town from new debris flows and to renew this beautiful tourist site.

I want to notice that rapid erosion of the dam's body could be supported by intensive comminution of the internal part of the blockage. As soon as coarse blocky carapace was removed by surge waves produced by debris flows entering the lake, nothing could prevent further incision. This peculiarity of large rockslide dams will be described in more details in the section devoted to old breached dams internal structure.

\section{2 The 1966 Yashinkul Lake catastrophe}

Another well-known catastrophic outburst flood caused by the rockslide dam breach had occurred on June 18, 1966 in the Isfairamsay River basin in Southern Kyrgyzstan (No. 14). The $20-30 \times 10^{6} \mathrm{~m}^{3}$ rockslide composed of Paleozoic metasediments debris originated about 300 years ago, likely being triggered by an earthquake. It formed a dam about $100 \mathrm{~m}$ high that blocked the Tegermach River valley (right tributary of the Isfairamsay River) at $39^{\circ} 55.6^{\prime} \mathrm{N}, 72^{\circ} 18^{\prime} \mathrm{E}$ and created the Yashinkul Lake (Rezvoi \& Rezvoi, 1969, Rezvoi et al., 1971, Reizvikh et al, 1971). In June 1966 the dam was overtopped due to continuous raining. Outburst flood that lasted for about 7 hours with peak discharge of $5000 \mathrm{~m}^{3} / \mathrm{s}$ caused significant damage not only in Kyrgyzstan but also in Uzbekistan. Unlike the Issyk Lake that was partially reimpounded afterward,
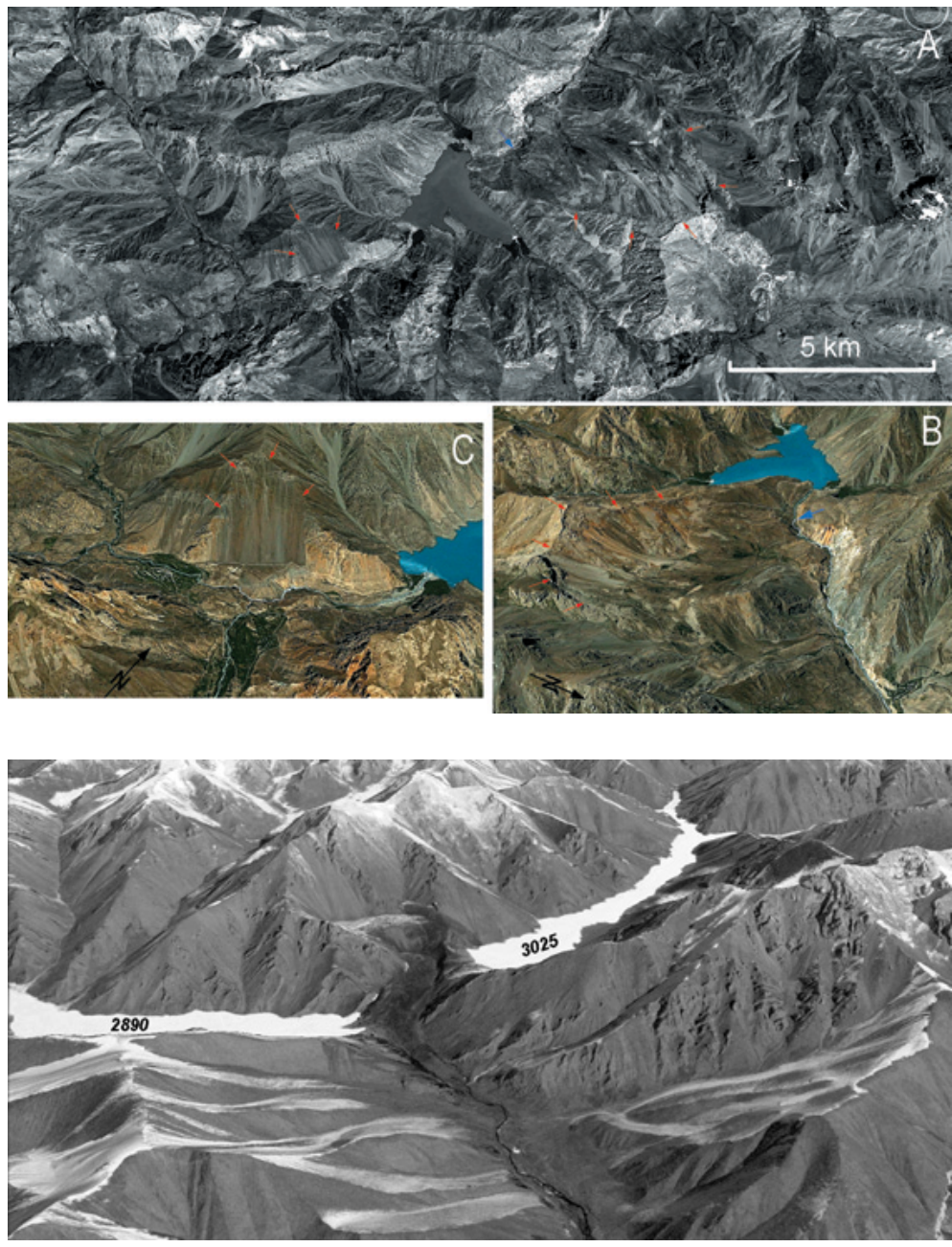

Fig. 7

Twin-Lakes Rockslide in Chinese Tien Shan damming two lakes, which levels differs for $135 \mathrm{~m}$. Perspective Google Earth image
Google Earth (QuickBird) views of the Iskanderkul dammed lake. A - an overview; B-perspective view of the Iskanderkul dam; $\mathrm{C}$-perspective view of the breached rockslide dam upstream from the Iskanderkul lake. Red arrows mark headscarps ; thin white lines outline rockslide bodies; blue arrow on Figures A and Bwaterfall in the central part of the canyon eroded through the Iskanderkul dam; green planar areas on Figure $\mathrm{C}$ are partially filled past dammed lakes 
the Yashinkul Lake disappeared completely through the canyon up to $90 \mathrm{~m}$ deep, $50-60 \mathrm{~m}$ wide at its bottom and 280-340 $\mathrm{m}$ wide at the dams' crest level (Neshikhovskiy, 1988). Thus, about $10 \times 10^{6} \mathrm{~m}^{3}$ of debris (from one third to one half of the entire rockslide volume) was removed from the dams' body causing significant aggradation downstream.

\section{3 The 1964 Aini Blockage - the averted disaster}

Recent river-damming rockslide that could result in a terrible disaster which was, however, prevented by timely arranged measures, occurred on April 24, 1964 in Tajikistan close to the junction of the Zeravshan and Fandaria Rivers just upstream from the Aini town $\left(39^{\circ} 23^{\prime} \mathrm{N}, 68^{\circ} 32.5^{\prime} \mathrm{E}\right)$ (No. 15). 20 million cubic meters of debris blocked the Zeravshan valley by a dam up to $150 \mathrm{~m}$ high (maximal height, the effective one was much lower, about 50-60 m only) and $\sim 1 \mathrm{~km}$ along the stream. Dammed lake fed by both rivers with cumulative discharge of about $90 \mathrm{~m}^{3} / \mathrm{s}$ (in April-May, 1964 ; mean annual discharge at this gauge is $147 \mathrm{~m}^{3} / \mathrm{s}$, according to State Water Inventory) started inundating. It could store up to $126 \times 10^{6} \mathrm{~m}^{3}$ of water, which release would devastate lower part of the Zeravshan River valley and ancient Samarkand City. The situation, however, was under control and the $865 \mathrm{~m}$ long and up to $23 \mathrm{~m}$ deep trench across the dams' crest was excavated by directed blasts. On May 6 water started passing through this artificial channel and 2 days later the discharge exceeded the inflow. The peak discharge of $1200 \mathrm{~m}^{3} / \mathrm{s}$ was recorded on May 31 . Lake was almost emptied at June 20, when its level dropped for $32.5 \mathrm{~m}$. Three millions cubic meters of debris was eroded from the dam resulting in significant aggradation of the Zeravshan River channel. The prerockslide level of the stream has not been reached yet (Neshikhovskiy, 1988). This case study is one of the first examples of the successful prevention of the rockslide dam breach disaster.

\section{Past rockslide dams, their evolution and internal structure}

\section{1 Rockslide-dammed lakes filled by sediments}

River damming in mountainous regions with significant sediment yield typical of most of streams, especially during flood period, finally results either in dam breach or in lake siltation. Several landslide-dammed lakes in Central Asian region were filled by lacustrine sediments completely or partially and drained so that flat areas favorable for agriculture and housing remain upstream (see Fig. 5 -C). It allows estimating the longevity of river valleys damming, which can help to predict long-term evolution of the existing rockslidedammed lakes described above.

\subsubsection{The Karakul rockslide dam and silted lake} (No. 6)

The Karakul rockslide about $300 \times 10^{6} \mathrm{~m}^{3}$ in volume had blocked the Karasu-Left River mouth at $41^{\circ} 38^{\prime} \mathrm{N}$, $72^{\circ} 39^{\prime}$ E. Rockslide caved from the slope composed of the Devonian limestone thrusted over the Permian sandstone and conglomerate. Besides the Karasu-Left River mouth it had blocked the Naryn River channel as well, but powerful Naryn had eroded its part of the dam completely, while Karasu had impounded the $\sim 200 \mathrm{~m}$ deep lake and found its way through the bedrock bench that appeared to be lower than the crest of the dam composed of the Devonian limestone debris. In time the lake was completely filled by sediments. Now this flat area is occupied by the Karakul town (Photo 4).

According to OSL (optically simulated luminiscence) dating performed by Dr. Yeong Bae Seong from Korea University, siltation should last up to 4.1-2.9 ka BP and even later (silt material was sampled from the upper part of the lake sediments, though not exactly from its top). It can be hypothesized that formation of the above-mentioned Karasu (No. 5) and Kapkatash (No. 5a) rockslide dams that blocks the same river in its upper reaches (see Fig. 4) took place after the formation of the Karakul natural dam. Otherwise river could hardly bring such a large amount of material to infill the Karakul lake. Moreover, the Karakol River that also had fallen into this water body (the KarasuLeft and Karakol Rivers present day cumulative mean discharge is $9 \mathrm{~m}^{3} / \mathrm{s}$, according to State Water Inventory), had been blocked by a gigantic Dead Lakes (No. 28) rock avalanche that had occurred on the slope composed of Paleozoic metasediments (Strom, Korup, 2005). Its age is estimated as $42-47 \mathrm{ka}$ (according to ${ }^{10} \mathrm{Be}$ dating performed by Dr. Seong). This assumption provides additional, though indirect estimates of the Karasu rockslide age lower limit - it should be younger than $\sim 2.9 \mathrm{ka}$.

\subsubsection{The Beshkiol rockslide dam (No. 16)}

The case study of an affluent river damming that resulted in almost complete siltation of the dammed lake could be found at $41^{\circ} 26^{\prime} \mathrm{N}, 74^{\circ} 29^{\prime} \mathrm{E}$, where the Naryn River crosses the Western Akshiyriak Range (Strom, 1998, 2005, Strom and Korup, 2005, Korup et al. 2006, 2007). Gigantic $\left(\sim 10 \mathrm{~km}^{3}\right)$ landslide in Neogene continental sediments (sandstone, mudstone with gypsum interbeds) mainly and in Paleozoic rocks at its proximal part had blocked the Naryn River valley at a distance of about $7 \mathrm{~km}$. The dam was up to $300 \mathrm{~m}$ high and filled the valley slightly above the level of a tectonic bench on its right side ( $\sim 1740$ m.a.s.l.). Unlike most of the above-mentioned permanent rockslide dams that blocked relatively small rivers and remain for centuries and millenia, this case study represents long-term 


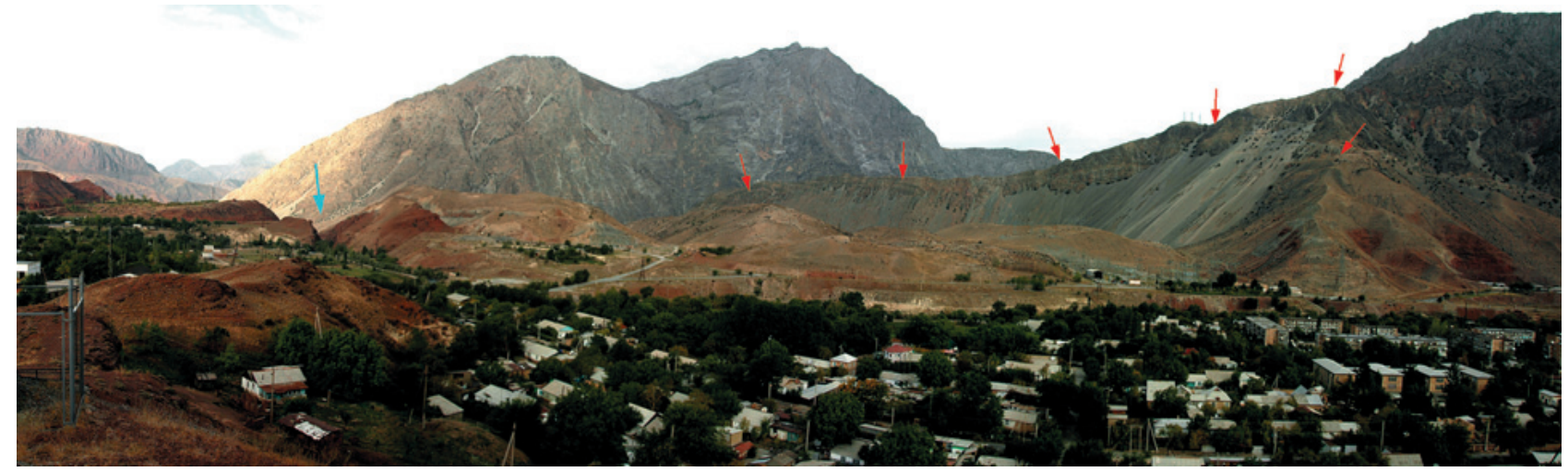

Photo 4 Silted rockslide-dammed lake area occupied by the Karakul town (at the foreground). Hilly area at the background - the rockslide dam originated from the headscarp marked by red arrows. The source zone is composed of the Devonian limestone thrusted over the Permian red conglomerate. The Karasu-Left River bypasses the dam through the triangular gorge at the left part of the panorama (blue arrow)

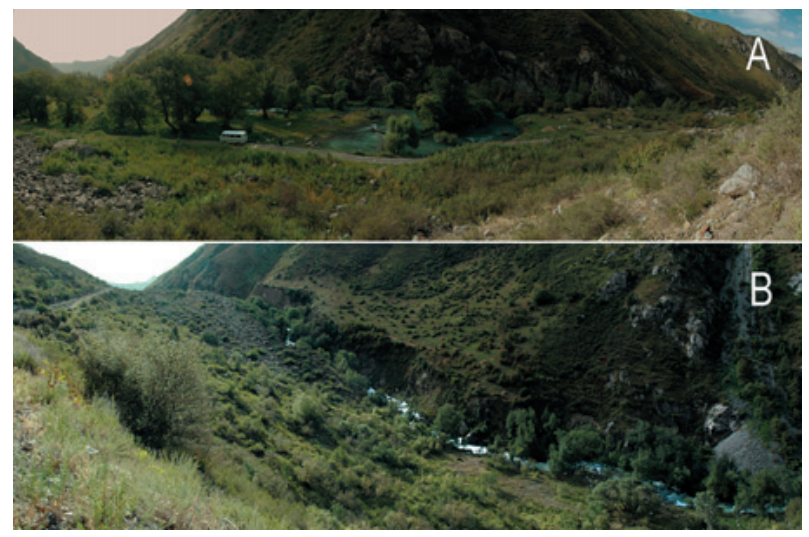

Photo 5 Upstream (A) and downstream (B) views on the rockslide-dam at the Kulun River mouth

damming of the powerful river with mean discharge of about $200 \mathrm{~m}^{3} / \mathrm{s}$ (State Water Inventory) that accumulates from the $31,300 \mathrm{~km}^{2}$ catchment. Assuming that river's annual runoff and sediment yield at that time was of the same order as at present, the lake that had extended for about $80 \mathrm{~km}$ upstream (Fig. 8) should be impounded in few years. After that water had found its new way not over the dam's crest, though some evidence of piping through the Neogene debris intercalated with solution-prone gypsum beds are visible, but bypassed the dam over the above-mentioned tectonic bench composed of hard Paleozoic rocks. Before sinu- ous, $10 \mathrm{~km}$ long and $\sim 250 \mathrm{~m}$ deep bypass gorge has been eroded, lake was silted up to $\sim 1650$ m.a.s.l., for about $2 / 3$ of its assumed depth. Dividing the estimated siltation volume by the mean annual sediment yield we found that river damming had lasted for 3000-4000 years (Korup et al., 2006). Later on significant portion of lake sediments was washed out. It can be hypothesized that when the hard bedrock obstacle was cut through, further rivers' incision into soft lake sediments could be quite rapid (Korup et al., 2007). It should increase sediment yield drastically and leave some imprints in the alluvium downstream.

I want to point out that large amount of fine sediments in the Naryn River valley upstream from its crossing with the Western Akshiyriak Range was erroneously interpreted as the effect of the latter's rapid tectonic uplift (Makarov, 1977). It demonstrates the importance of the landslide damming phenomena correct interpretation for better understanding not only of the river valleys' evolution but of the regional neotectonics as well.

\subsubsection{The Kulun River valley rockslide dams}

The complete siltation of the rockslide-dammed lake could be observed at the Kulun River mouth. This right tributary of the Tar River had been dammed twice - in its upper reaches at $40^{\circ} 32^{\prime} \mathrm{N}, 74^{\circ} 17.2^{\prime} \mathrm{E}$, where the $90 \mathrm{~m}$ deep Kulun Lake (No. 17) still exist

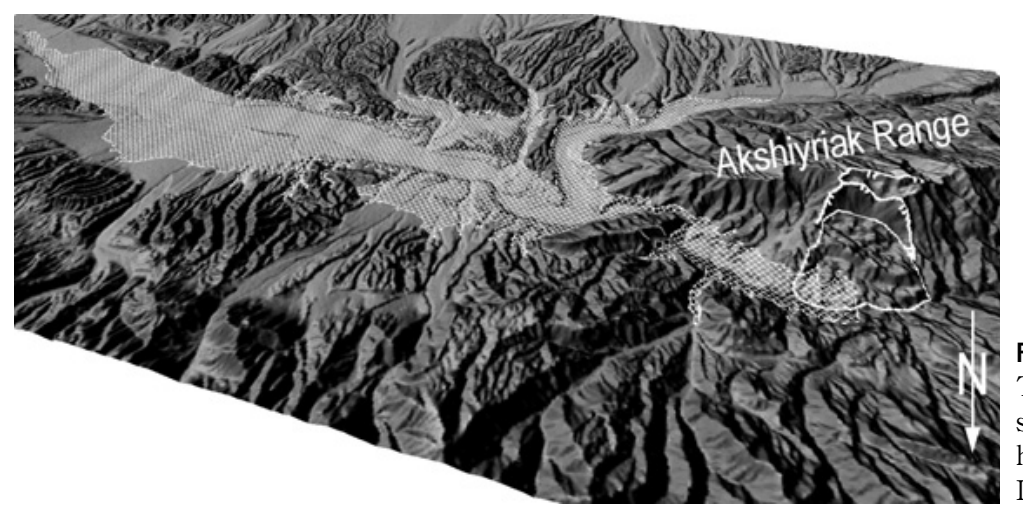

Fig. 8

The Beshkiol rockslide dam and former lake at its assumed level of 1740 m.a.s.l. marked by diagonal cross hatch. Perspective view compiled from the 3" SRTM DEM 
and at $40^{\circ} 27.6^{\prime} \mathrm{N}, 74^{\circ} 04.2^{\prime} \mathrm{E}$, just upstream from its mouth. Here the Kulun-mouth rockslide (No. 18) that had caved from the top of the right bank composed of Paleozoic limestone, had formed a $70 \mathrm{~m}$ high dam and $6.5 \mathrm{~km}$ long lake. Later on this lake was silted completely (Photo 5).

It can be hypothesized that presence of the $250 \mathrm{~m}$ high blockage damming the Kulun Lake in the upper reaches of the same valley provides significant runoff control and decreases peak discharge, thus supporting gradual siltation of the downstream water body.

\section{2 Peculiarities of the breached rockslide dams internal structure}

As mentioned above, most of the Central Asian rockslide dams have been breached and deeply eroded providing excellent opportunity to study internal structure and grain-size composition of rockslide deposits (Strom, 2006). Several examples of such breached dams could be found in the Central and Northern Tien Shan (Abdrakhmatov, Strom, 2006). One of the most interesting case studies is the Kokomeren rockslide (No. 20) located in the same name river valley at $41^{\circ}$ 55. $5^{\prime} \mathrm{N}, 74^{\circ} 13.5^{\prime} \mathrm{E}$, downstream from the small KyzylOi intermountain depression (Strom, 1994, 2006). Its most detail description could be found in (Strom, Ab-

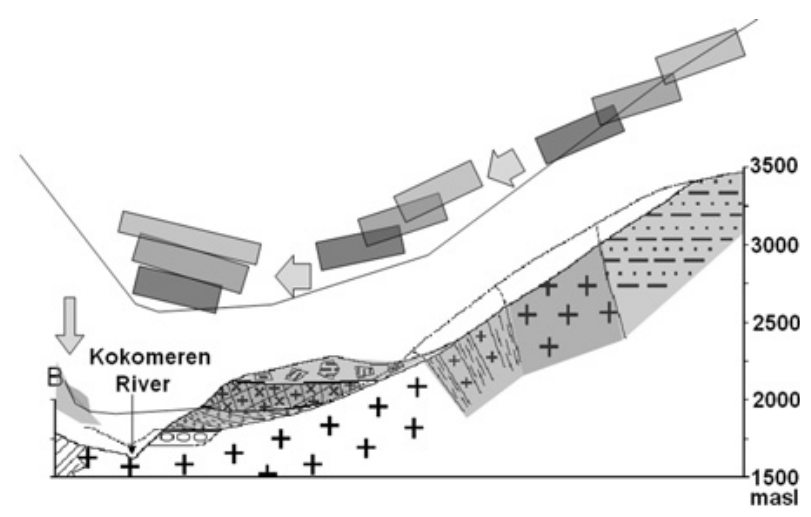

Fig. 9 Model of the Kokomeren rockslide emplacement mechanism (after Hartvich, et al. 2008)

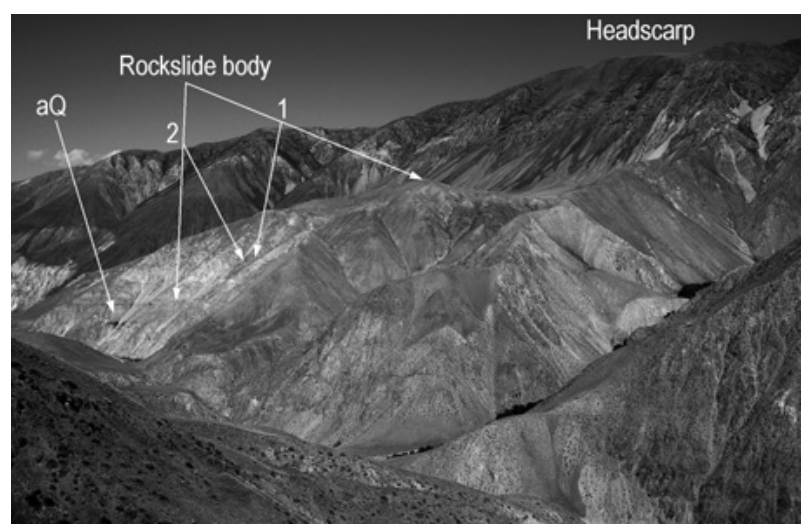

Photo 6 Deeply eroded Kokomeren rockslide dam. aQ-Late Pleistocene strath terrace alluvium underlying rockslide body ; 1-coarse blocky zone ; 2-fine-grained shattered zone drakhmatov, 2009) available at http ://www.iclhq.org/.

This Pleistocene rockslide originated most likely due to a strong earthquake (Strom, Stepanchikova, 2008). From 1.0 to $1.5 \mathrm{~km}^{3}$ of rock collapsed from the 1600 $\mathrm{m}$ high slope composed of alteration of various multicolored sedimentary and igneous rocks - dark-gray shale, reddish granite, alternating red granite and dark -gray sandstone, possibly with some fault zones. Expressive variability of rock types involved in this slope failure (Photo 6) allows reconstruction of the emplacement mechanism, which model is presented on Fig. 9 (Strom, 1994, 2006, Hartvich et al., 2008).

While main part of the rockslide body rests on the $\sim 150 \mathrm{~m}$ high river terrace, its frontal part had filled the Pleistocene river channel, which was about $50 \mathrm{~m}$ above the present-day riverbed. This part was almost completely eroded except its small portion that fills remnant of an old river channel on the modern valley right bank. Here, similar to the Beshkiol case (No. 16), the new gorge has been cut through the bedrock that should slow down the process of dams' breach significantly. The blockage with effective height of $\sim 200 \mathrm{~m}$ (Hartvich, et al. 2008) had formed the lake $\sim 1 \mathrm{~km}^{3}$ in volume that had been impounded less than in one year by powerful Kokomeren, which present-day mean annual runoff is $\sim 2,5 \times 10^{9} \mathrm{~m}^{3} /$ year (State Water Inventory). Presence of nearly $10^{8} \mathrm{~m}^{3}$ of well-bedded lacustrine sediments indicates that river damming could last for few centuries at least.

Two major zones can be distinguished in this natural dam. The upper one about 200-250 m thick is composed of coarse blocks and large massifs of fractured reddish granite, overlaid, in its turn, by the gray 'layer' of angular boulders of metasediments and shale ( 1 on Photo 6). In contrast, the lower zone, up to $150-200 \mathrm{~m}$ thick (2 on Photo 6 ), consists of heavily shattered rocks, divided into some unmixed 'layers' of granite and metasediment fragments. Besides intensive comminution, lower part of the Kokomeren rockslide dam as well as of other large-scale rockslides is characterized by dense compaction of angular or scale-like particles that makes it almost impermeable. It explains sharp heterogeneity of filtration through high natural dams as the Usoi blockage - water passes through their blockys carapaces only that blankets giant and almost impermeable cores.

The succession of debris 'layers' corresponds to the bedrock alternation in the headscarp (see Fig. 9). It demonstrates that this part of sliding mass, up to 150 $200 \mathrm{~m}$ thick, moved as a single whole, without turbulence and mixing. It is assumed that intensive shattering typical of the lower part of rockslide body took place during the emplacement.

'Stratification' of rockslide bodies and intensive crushing and compaction of debris that form cores of 


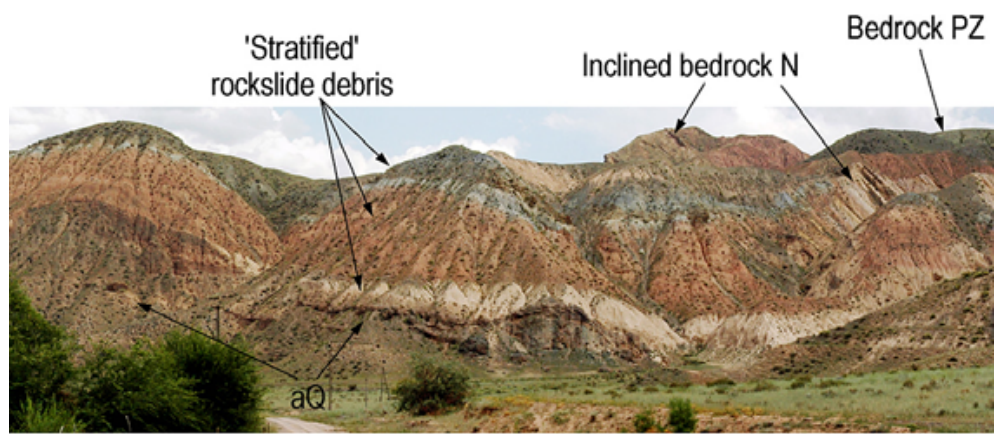

Photo 7

Debris 'stratification' of the Ornok rockslide that incorporates both Paleozoic rocks (gray units) and Neogene redbeds. Bedrock Neogene strata dipping $\sim 40^{\circ}$ are marked out at the zoomed fragment above. The entire horizontally-bedded succession represents 'stratified' rockslide body resting over the alluvium $(\mathrm{aQ})$. It should be noticed that the uppermost gray-color 'layer' originated from the Paleozoic rocks that form the topmost part of the headscarp (same as at the sketch on Figure 9)

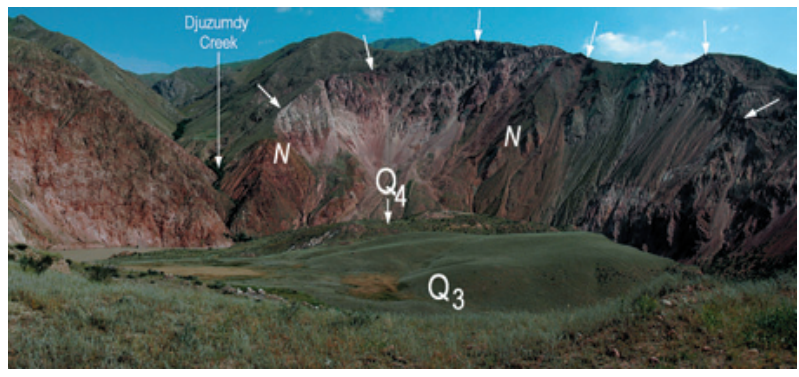

Photo 8 The Djuzumdy Bulak recurrent rockslides. $\mathrm{N}-\mathrm{Neo}-$ gene sediments bounded by oncoming reverse faults pink outcrops above and aside from the Neogene are Paleozoic granite; smooth surface marked as $\mathrm{Q}_{3}$ as well as the stony hill at the foreground-body of the Late Pleistocene rock avalanche; hummocky hill marked as $\mathrm{Q}_{4}$ - the Holocene rockslide body; arrows mark the headscarp crown

such natural dams was observed at many other deeply eroded rockslide dams in Central Asia (Abdrakhmatov, Strom, 2006, Strom, 1994, 2006). Among them are the $400 \mathrm{Mm}^{3}$ Djashilkul rockslide (No. 21) in the ChonKemin River valley $\left(42^{\circ} 46.7^{\prime} \mathrm{N}, 76^{\circ} 22^{\prime} \mathrm{E}\right)$, and $\sim 15$ $\mathrm{Mm}^{3}$ Arashan rockslide (No. 22) in the Alamedin River valley $\left(42^{\circ} 36.5^{\prime} \mathrm{N}, 74^{\circ} 40^{\prime} \mathrm{E}\right)$ close to Bishkek City. The most impressive 'stratification' can be observed at Ornok rockslide (No. 32) in the Kokomeren River valley ( $41^{\circ} 43^{\prime} \mathrm{N}, 74^{\circ} 13.5^{\prime} \mathrm{E}$ ) (Photo 7 ).

\section{3 Recurrent river valley blocking}

Multiple rockslide formation at some local sections of river valleys is typical both of the Pamirs and the Tien Shan. It was described, in particular, by Fedorenko (1988) and by Strom \& Abdrakhmatov (2004). This phenomenon can be considered as an additional factor increasing probability of river damming at such parts of river valleys.

\subsubsection{The Djuzumdybulak recurrent rockslides (No. 29)}

An impressive example of recurrent river damming could be found in the Naryn River valley at $41^{\circ} 47^{\prime} \mathrm{N}$,

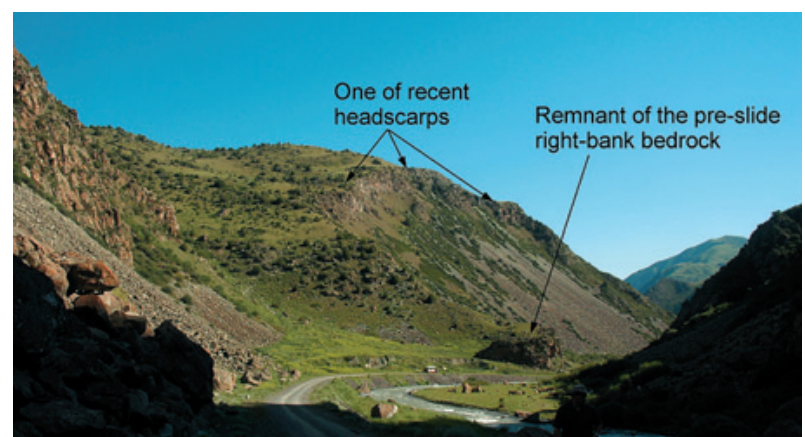

Photo 9 Upstream view of the $400 \mathrm{~m}$ high Aksu rockslide dam. The original river channel had passed left from the pre-slide bedrock remnant. The green meadow at the riverbank-silted lake dammed by recent landslide that caved from the main rockslide body

$73^{\circ} 24.2^{\prime} \mathrm{E}$, immediately upstream from the mouth of its small tributary - the Djuzumdy Creek (the Djuzumdy Bulak in Kyrgyz) (Photo 8).

The Naryn River had been blocked here at least twice - in Late Pleistocene and in Holocene. Deposits of an older rock avalanche $15-25 \mathrm{Mm}^{3}$ in volume (marked by $\mathrm{Q}_{3}$ on Photo 8) rest on several strath terraces from 50 to almost $100 \mathrm{~m}$ high over which it moved for 1.7 $\mathrm{km}$ climbing up as if over giant steps. Most of rock avalanche debris accumulated at the distal part of the depositional zone. Low dam formed by this event was eroded at its proximal part. Further incision led to slope undercutting that, likely along with strong (M 7.5) earthquake that occurred almost 2000 years BP (Belousov, et al. 1994), caused next rockslide of the same order of size (about $20 \mathrm{Mm}^{3}$ ). It filled the canyon and formed $\sim 50 \mathrm{~m}$ high dam (marked by $\mathrm{Q}_{4}$ on Photo 8). This blockage was also breached at its proximal part. Large amount of loose deposits (both rockslide debris and scree) resting in the headscarp is potentially unstable. According to unverified data short-term stream blocking at this site occurred in 1992 being triggered by the M7. 3 Suusamyr earthquake. 
Headscarp from which these rockslides caved, is composed of Paleozoic granite crossed by active reverse faults bounding narrow 'stripe' of Neogene sediments (see Photo 8). Earthquakes, which, most likely, triggered both rockslides, were associated with this fault zone (Belousov et al., 1994). Due to combination of active tectonics, steep slope and river erosion this site should be still considered as a rockslide-prone one.

\subsubsection{Successive landslide damming of the Aksu River valley (No. 19)}

Deeply incised rockslide dams form valley slopes up to several hundreds meters high composed of intensively comminuted debris overlaid by coarse blocky carapace. Being undercut by erosion they could produce large subsequent landslides, which, in turn, also block river channels. Such successive river damming can be exemplified by the case study from the Aksu River valley that dissects the northern slope of the Kyrgyz Range.

About $1.5 \mathrm{~km}^{3}$ of granite and metasediments collapsed from the $1800 \mathrm{~m}$ high right slope of the valley in Late Pleistocene and formed the compact Aksu blockage with effective height of about $400 \mathrm{~m}$ at $42^{\circ}$ $32.5^{\prime} \mathrm{N}, 74^{\circ} \mathrm{E}$ (Photo 9). Considering the present-day annual runoff of $140 \mathrm{Mm}^{3}$ (State Water Inventory) the Aksu dam should be overtopped less than in one year. Judging from the absence of lacustrine sediments upstream we hypothesize that the rate of erosion that should start at the lowermost proximal part of the dam's crest was rather high. It should, however, slow down when the stream incised the bedrock, which remnants are on the left bank of the modern stream both at the up- (see Photo 9) and downstream blockage limits. Finally the dam was dissected completely and now almost $500 \mathrm{~m}$ high left slope of this new valley is composed of rockslide debris.

Its distinct concave shape indicates at least two episodes of subsequent failures several millions cubic meters in volume each. One of such headscarp can be seen on Photo 9. Another most recent and much bigger subsequent landslide not visible on this photo blocked the valley by a dam several dozens meters high. A meadow on Photo 9 foreground is a small dammed lake rapidly filled by sediments, while rapids and waterfalls represent kilometer-long section of the river downstream. Most likely this recent landslide was triggered by strong $(\mathrm{M} \sim 7.0) 1885$ Belovodsk earthquake that occurred about $15-20 \mathrm{~km}$ north from the rockslide site at the Kyrgyz Range foothills. This assumption is supported by the notice made by I.V. Ignatiev, who visited the area for reconnaissance. He wrote that "...water flow in the Aksu River stopped for some time after the earthquake" (Ignatiev, 1886). No other evidence of river damming that could result in such effect are known in the valley. Landslides that originate from the slopes incised in large rockslide bodies are the 'tertiary' hazardous consequence of largescale rockslide river damming.

\section{Discussion - factors determining landslide dam evolution}

Most of case studies described above and listed in Table 1 follow the regularity quantified by the 'Dimensionless Blockage Index': DBI $=\log \left(\mathrm{A}_{b} \mathrm{H}_{d} / \mathrm{V}_{\mathrm{d}}\right)$ where $A_{b}$ is the upstream catchment area, $H_{d}$ is the dam height, $V_{d}$ is the landslide dam volume (Ermini, Casagli, 2003). Some of them, however, demonstrate anomalous behavior (Fig. 10), which can be explained if we consider some additional quantitative parameters characterizing landslide dams and dammed lakes.

Role of such factors can be revealed from comparative analysis of case studies that demonstrate antithetic deviation from the behavior that could be expected according to DBI value. One can compare the long-living Yashilkul rockslide dam (No. 2) in the Pamirs (DBI $=3.71$, which correspond to the instability domain) and the gigantic Aksu rockslide (No. 19) in the Tien Shan, which was breached rather soon after its origin, regardless low DBI value (1.94 - within

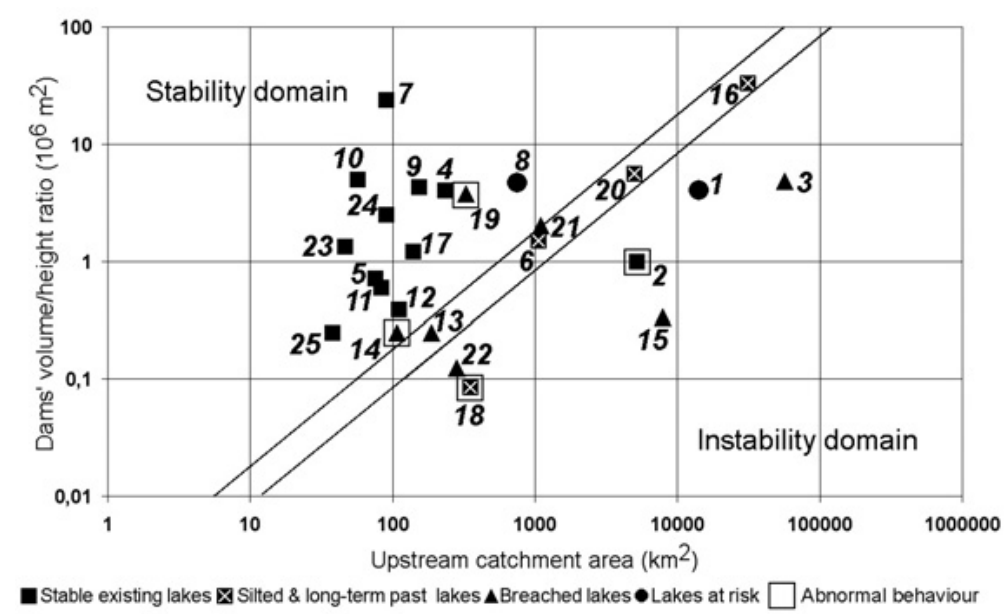

Fig. 10 Volumes of rockslide dams scaled by height versus upstream catchment area for case studies listed in Table 1 (numbers are the same as in Table 1 and Figure 1) 
Table 1 Some basic parameters of rockslide dams described above

\begin{tabular}{|c|c|c|c|c|c|c|c|c|}
\hline \multirow[t]{2}{*}{ No } & \multirow{2}{*}{$\begin{array}{l}\text { Region / } \\
\text { River }\end{array}$} & \multirow[t]{2}{*}{ Rockslide Dam } & \multirow{2}{*}{$\begin{array}{l}\text { Lake (existing, } \\
\text { filled, breached) }\end{array}$} & \multicolumn{2}{|c|}{ Dams' parameters \# } & \multirow{2}{*}{$\begin{array}{l}\text { Catchment } \\
\text { area }\left(\mathrm{km}^{2}\right)\end{array}$} & \multirow[t]{2}{*}{ DBI } & \multirow{2}{*}{$\begin{array}{l}\text { DBI }<2.75-\text { stability domain }(\mathrm{S}) \\
2.75<\mathrm{DBI}<3.08 \text { uncertain domain }(\mathrm{U}) \\
\text { DBI }>3.08 \text { instability domain }(\mathrm{I}) / \\
\text { additional comments }\end{array}$} \\
\hline & & & & $\begin{array}{l}\text { volume } \\
\left(10^{6} \mathrm{~m}^{3}\right)\end{array}$ & \begin{tabular}{|l|} 
effective \\
height \\
(m)
\end{tabular} & & & \\
\hline 1 & $\begin{array}{l}\text { Pamirs / } \\
\text { Murgab }\end{array}$ & 1911 Usoi & Existing & 2200 & 550 & 14,166 & 3.55 & $\begin{array}{l}\text { I / Should be considered as being at } \\
\text { risk }\end{array}$ \\
\hline 2 & Pamirs /Gunt & Yashilkul & Existing & 50 & 50 & 5,166 & 3.71 & I / Permanent lake with stable dam \\
\hline 3 & Pamirs /Pianj & Shids & Partially breached & 1200 & 250 & 57,100 & 4.08 & I / Small remnant lake still exist \\
\hline 4 & Pamirs /Shiva & Shiva & Existing & 2000 & 500 & 232 & 1.76 & $\mathrm{~S}$ \\
\hline 5 & $\begin{array}{l}\text { Tien Shan / } \\
\text { Karasu-Left }\end{array}$ & Karasu & Existing & 250 & 350 & 75 & 2.02 & $\mathrm{~S}$ \\
\hline 6 & $\begin{array}{l}\text { Tien Shan / } \\
\text { Karasu-Left }\end{array}$ & Karakul & $\begin{array}{|ll|}\begin{array}{l}\text { Filled by sedi- } \\
\text { ments }\end{array} & \\
\end{array}$ & 300 & 200 & 1063 & 2.85 & $\begin{array}{l}\mathrm{U} / \text { Lake had existed for a long time } \\
\text { and was silted completely }\end{array}$ \\
\hline 7 & \begin{tabular}{|l|} 
Tien Shan / \\
Karasu-Right
\end{tabular} & Sarychelek & Existing & 6000 & 250 & 90 & 0.57 & S \\
\hline 8 & $\begin{array}{l}\text { Tien Shan / } \\
\text { Iskanderkul- } \\
\text { Daria } \\
\end{array}$ & Iskanderkul & Existing & 700 & 150 & 752 & 2.21 & $\begin{array}{l}\text { S / Should be considered as being at } \\
\text { risk due to surficial outflow and } \\
\text { intensive backward erosion }\end{array}$ \\
\hline 9 & Tien Shan & Tianchi & Existing & 1500 & 350 & 153 & 1.55 & $\mathrm{~S}$ \\
\hline 10 & Tien Shan & Big Dragon & Existing & 2000 & 400 & 57 & 1.06 & $\mathrm{~S}$ \\
\hline 11 & Tien Shan & $\begin{array}{l}\text { Twin-Lakes } \\
\text { (Damming } \\
\text { upper Lake) }\end{array}$ & Existing & 150 & 250 & 83 & 2.14 & $\mathrm{~S}$ \\
\hline 12 & Tien Shan & $\begin{array}{l}\text { Twin-Lakes } \\
\text { (Damming } \\
\text { lower Lake) }\end{array}$ & Existing & 50 & 130 & 111 & 2.46 & $\mathrm{~S}$ \\
\hline 13 & $\begin{array}{l}\text { Tien Shan / } \\
\text { Issyk }\end{array}$ & Issyk & Breached in 1963 & 25 & 100 & 189 & 2.87 & $\begin{array}{l}\text { U / Lake had existed for a long time. } \\
\text { Dam was breached by debris flow } \\
\text { caused by the upstream lake outburst }\end{array}$ \\
\hline 14 & $\begin{array}{l}\text { Tien Shan / } \\
\text { Tegermach }\end{array}$ & Yashinkul & Breached in 1966 & 25 & 100 & 107 & 2.63 & $\begin{array}{l}\text { S / Lake had existed for a long time. } \\
\text { Dam was breached after rainstorm }\end{array}$ \\
\hline 15 & $\begin{array}{l}\text { Tien Shan / } \\
\text { Zeravshan }\end{array}$ & 1964 Aini & $\begin{array}{l}\text { Dammed lake was } \\
\text { drained artificially }\end{array}$ & 20 & 60 & 7,950 & 4.38 & I / Lake was drained artificially \\
\hline 16 & $\begin{array}{l}\text { Tien Shan / } \\
\text { Naryn }\end{array}$ & Beshkiol & $\begin{array}{l}\text { Prehistoric lake } \\
\text { breached after } \\
\text { almost complete } \\
\text { siltation } \\
\end{array}$ & 10000 & 300 & 31,300 & 2.97 & $\begin{array}{l}\text { U / Lake had existed for a long time. } \\
\text { Bypass gorge has been eroded gradu- } \\
\text { ally through the bedrock close to the } \\
\text { dams' distal boundary }\end{array}$ \\
\hline 17 & $\begin{array}{l}\text { Tien Shan / } \\
\text { Kulun }\end{array}$ & Kulun & Existing & 300 & 250 & 140 & 2.07 & S \\
\hline 18 & $\begin{array}{l}\text { Tien Shan / } \\
\text { Kulun }\end{array}$ & Kulun-Mouth & \begin{tabular}{|l} 
Filled by sedi- \\
ments
\end{tabular} & 6 & 70 & 353 & 3.61 & $\begin{array}{l}\text { I / Lake had existed for a long time } \\
\text { and was silted completely }\end{array}$ \\
\hline 19 & $\begin{array}{l}\text { Tien Shan / } \\
\text { Aksu }\end{array}$ & Aksu & Breached & 1500 & 400 & 329 & 1.94 & $\begin{array}{l}\text { S / Dam was breached soon, likely } \\
\text { few years after its formation }\end{array}$ \\
\hline 20 & $\begin{array}{l}\text { Tien Shan / } \\
\text { Kokomeren }\end{array}$ & Kokomeren & Breached & $\begin{array}{r}1000 \\
(1500)\end{array}$ & $\begin{array}{r}200 \\
(250)\end{array}$ & 4,946 & \begin{tabular}{|l|}
3.0 \\
$(2.92)$ \\
\end{tabular} & $\begin{array}{l}\text { U / Lake had existed for a long time. } \\
\text { New gorge has been eroded gradually } \\
\text { through the bedrock }\end{array}$ \\
\hline 21 & \begin{tabular}{|l|} 
Tien Shan / \\
Chong- \\
Kemin \\
\end{tabular} & Djashilkul & Breached & 400 & 200 & 1,093 & 2.74 & $\begin{array}{l}\text { U / Dam was breached soon, likely } \\
\text { few years after its formation }\end{array}$ \\
\hline 22 & $\begin{array}{l}\text { Tien Shan / } \\
\text { Alamedin } \\
\end{array}$ & Arashan & Breached & 5 & 40 & 283 & 3.35 & I \\
\hline 23 & $\begin{array}{l}\text { Tien Shan / } \\
\text { Mailusuu }\end{array}$ & Kutmankul & Existing & 200 & 150 & 46 & 1.54 & S \\
\hline 24 & \begin{tabular}{|l|} 
Tien Shan / \\
Bolshaya \\
Almatinka \\
\end{tabular} & $\begin{array}{l}\text { Bolshoe Al- } \\
\text { maty }\end{array}$ & Existing & 500 & 200 & 90 & 1.56 & S \\
\hline 25 & $\begin{array}{l}\text { Tien Shan / } \\
\text { Badak }\end{array}$ & Badak & Existing & 30 & 120 & 37.5 & 2.18 & S \\
\hline
\end{tabular}

\# rough estimates based on remote sensing mapping and 3" SRTM DEM analysis

the stability domain). Both rivers have almost the same mean runoff of about $140-145 \mathrm{Mm}^{3} /$ year (State Water Inventory). I assume that such 'inverse' behavior is determined by combination of two factors - shape of the blockage and the upstream valley morphology.
The $\sim 50 \mathrm{Mm}^{3}$ Yashilkul rockslide converted into rock avalanche that formed a $4 \mathrm{~km}$ long dam $50 \mathrm{~m}$ high only. Low-gradient flow over this dam can not erode meter-size blocks resting at the dams' crest. Besides, flat topography of the area upstream led to formation 
of large natural reservoir that reduces peak discharge during the flood period significantly. Both factors support dams' safety.

In contrast, the Aksu rockslide, almost 30 times bigger, formed a $400 \mathrm{~m}$ high dam that stretched along the river for $2.5 \mathrm{~km}$ only. Its downstream slope was so steep that overflowing water had eroded it rapidly. The dammed lake was deep but rather small due to high channel grade and could not regulate runoff significantly after initial impoundment. Thus, peak discharge passing through (over) this dam should be much bigger than in the Yashilkul case. In this case combination of both factors worked in favor of fast and complete breach of the blockage.

Quantitative expression of dams' compactness can be characterized by $\mathrm{H}_{d} / \mathrm{W}_{\mathrm{d}}$ ratio, where $\mathrm{H}_{\mathrm{d}}$ is the dam's effective height, and $\mathrm{W}_{\mathrm{d}}$ is the landslide dam width (length along the stream). Increase of this value decreases dams' ability to sustain the overflow. Capability of natural reservoir to reduce peak discharge can be quantified, as a first approximation, by the runoff during flood period $\left(R_{f}\right)$ divided by lake area $A_{L}$. Higher $R_{f} / A_{L}$ ratio means that overflow peak discharge should be bigger with higher erosive potential.

Another factor determining the landslide damming longevity is the across-valley dam profile. Two main groups of blockages can be discriminated: (A) - with proximal or central and (B) - with distal lowering. Rockslide dams with proximal/central lowering seem to be less stable then blockages with distal location of their lowermost parts. If erosion starts closer to the headscarp foot, it affects the rockslide debris through which a new channel could be incised rapidly, resulting in catastrophic outburst flood and river channel aggradation. Such phenomenon took place at the Djashilkul dam (No. 21, DBI = 2.74), for example. Similar acrossvalley profile was typical of the Pleistocene Aksu dam (No. 19). It characterizes the Usoi blockage (No. 1) too, increasing risk of its breach in case of overtopping.

In contrast, if the lowermost part of rockslide dam coincides with its distal edge, it is likely that overflowing stream would erode the bedrock of the opposite bank. Such situation can be exemplified by the Beshkiol (No. 16, DBI = 2.91), the Kokomeren (No. 20, DBI =2.92-3.0) and the Karakul (No. 6, DBI = 2. 85) dams, that had blocked rivers for centuries and millennia, despite of rivers' runoff. It results in significant, sometimes complete siltation of water bodies, especially if the river is not affluent and can not erode the bedrock barrier completely as it occurs in the Karakul case.

Presence of a blockage upstream, such as in cases of the Karakul (No. 6) and the Kulun-Mouth (No. 18) dams, should be considered as an additional factor decreasing peak discharge and favoring long-term river damming. Despite high DBI values (2.85 and 3.61 cor- respondingly) both lakes had existed for a long time being silted almost completely. In the Karakul case it was conditioned both by the presence of the Karasu Lake (No. 5) upstream and by the across-valley dams' profile. Long-term stability of the Kulun-Mouth blockage could be just due to significant reduction of peak discharge provided not only by its 'own' lake, but by the upstream Kulun Lake (No. 17) as well. It should be mentioned, however, that outburst of an upstream lake (even if it is much smaller than the downstream one) can cause catastrophic breach of the downstream blockage, as it occurred in 1963 in the Issyk River ba$\sin$ (No. 13).

Quantitative estimates of the importance of all these factors can be done on the basis of statistical analysis, which, in turn, requires uniform inventory of the Central Asian landslide dams similar to those, available for the Alps, Apennines or New Zealand (Abele, 1974, Casagli and Ermini, 1999 ; Ermini, et al., 2006 ; Korup, 2004). Compilation of such inventory for the entire Tien Shan mountainous system that belongs for 5 countries - China, Kazakhstan, Kyrgyzstan, Tajikistan, and Uzbekistan is performed within the IPL (International Program on Landslides) Project.

At least two of the existing natural dams described above, i. e. the Usoi dam (with the Sarez Lake) in Pamirs (No. 1, DBI = 3.55) and the Iskanderkul dam in the Tien Shan (No. 8, DBI =2.21) seems to be at risk. The first one, which DBI is within the instability domain, could remain for about 100 years (since 1911) due to its enormous size that provides permeable zone large enough to filter the inflow through the dams' body. Nevertheless, high long-term risk of its breach is determined by several factors: possibility of runoff increase due to climate change, potential instability of the Sarez Lake banks, backward erosion in the channel developing on the downstream slope of the blockage, distinct crest lowering at the proximal part of the blockage, internal deformations of the dam that can affect the filtration and reduce dams' stability.

Hazardous state of the Iskanderkul dam, which, according to its low DBI value, should be considered as a stable feature, could be proposed due to distinct evidence of the intensive backward erosion in the canyon incised in the dams' body. If the Iskanderkul-Daria River discharge would increase, even temporary, above its present level, the erosion rate could increase as well resulting in dam failure. High seismicity of both the Pamirs and the Tien Shan increases overall risk.

It should be noticed that origin of several large natural dams in Pamirs is still debatable. I can mention, in particular, the gigantic, about $1 \mathrm{~km}^{3}$ in volume, breached blockage in the Kudara River valley (No. $30)$ at Pasor village $\left(38^{\circ} 23.5^{\prime} \mathrm{N}, 72^{\circ} 34.7^{\prime} \mathrm{E}\right)$ and the Rivakkul dam (No. 31) with small lake in the Gunt 
River basin $\left(37^{\circ} 37^{\prime} \mathrm{N}, 72^{\circ} 03.5^{\prime} \mathrm{E}\right.$ ) (No. 30 and 31 on Fig. 1). According to Nikolai and Anatoliy Ischuk opinion, based on the presence of large amount of moraine material in these blockages, they have been formed by end moraines (Anatoliy Ischuk, personal communication). From my point of view, most of such blockages have been formed by rockslides and presence of coarse rounded boulders can be explained by pushing of moraine material resting on the slopes of Pamirs river valleys by rapidly moving rockslide debris (as it was described in the Yashilkul rockslide case - No. 2). However, final solution of this problem requires additional field studies at each questionable site.

\section{Conclusions}

Central Asia region characterized by rugged terrain and excellent outcropping supported by arid climate is one of the world-best natural laboratories to study large landslides and landslide-related phenomena, river damming in particular. Being rich of both existing and breached rockslide dams it demonstrates various disturbance regime landscapes (Hewitt, 2006) resulting from different scenarios of rockslide river damming:

- Temporary (days - weeks - months - up to few years) damming, causing outburst floods and downstream aggradation soon after the initial lake impoundment that can be exemplified by the 1964 Aini (No. 15), and the prehistoric Shids (No. 3), Aksu (No. 19), Djashilkul (No. 21), and Djuzumdybulak (No. 29) rockslide dams.

- Permanent damming of low-discharge rivers that took place centuries or millennia ago by large-scale rockslides, which are still considered as stable and safe natural dams with large water bodies as Yashilkul (No. 2), Karasu (No. 5), Sarychelek (No. 7), Kulun (No. 17), Tianchi (No. 9), Big Dragon (No. 10), Kutmankul (No. 23), Badak (No. 25) Lakes.

- Permanent damming of a river that had lasted for a long time and, finally, resulted in almost complete lake siltation without dams' rupture like Karakul (No. 6) and Kulun-Mouth (No. 18) cases. Further evolution of such scenario can be exemplified by Beshkiol (No. 16) and Kokomeren (No. 20) past rockslide-dammed lakes that had also existed for centuries and millennia being silted at a large extent, but were emptied gradually when affluent rivers cut through the bedrock barriers.

- The most hazardous scenario is when a landslide dam that has existed for centuries, being considered as a stable feature, undergoes catastrophic failure due to extreme geological (e.g. earthquake), glacial (glacial lake outburst) or meteorological (rainstorm) phenomena as it happened in 1963 with Issyk dam (No. 13) and in 1966 with Yashinkul dam (No. 14).
Better knowledge of the regularities of the Central Asian rockslide dams evolution will allow to predict further behavior of any natural dam, the Usoi blockage (No. 1) in particular, and either to prevent or to minimize its potentially hazardous consequences.

\section{Acknowledgments}

I want to express my gratitude to Anatoliy and Nikolai Ischuk from Tajik Institute of Earthquake Engineering and Seismology, Oleg Zerkal from Moscow State University, Nicola Casagli from University of Firenze, Gonghui Wang from DPRI, Kyoto University, Fawu Wang from Shimane University, and Oliver Korup from Potsdam University for useful comments and discussions. Yeong Bae Seong from Korea University provided new data on landslide dams ages. Field studies in Kyrgyzstan were performed with Kanatbek Abdrakhmatov and his colleagues from Kyrgys Institute of Seismology. Comments of the anonymous reviewers helped to improve the manuscript. Compilation of the Tien Shan landslide inventory was supported by M126 IPL Project approved by International Consortium on Landslides.

\section{References}

Abdrakhmatov, K. E., Strom, A. L. (2006) : Dissected rockslide and rock avalanche deposits; Tien Shan Kyrgyzstan. In: Evans, S. G., Scarascia Mugnozza, G., Strom, A. L., Hermanns, R. L. (Eds.) Landslides from Massive Rock Slope Failure. NATO Science Series: IV: Earth and Environmental Sciences, Springer, Vol. 49, pp. $551-572$.

Abele, G. (1974) : Bergsturze in den Alpen. Ihre Verbreitung, Morphologie und Folgeerscheinungen. Wiss. Alpenvereinshefte, Vol. 25.

Belousov, T.P., Skobelev, S.F., Strom, A. L. (1994) : On estimation of the recurrence period of Strong earthquakes in the Central Tien Shan. Journal of Earthquake Prediction Research, Vol. 3, pp. $226-236$.

Casagli, N., Ermini L. (1999) : Geomorphic Analysis of Landslide Dams in the Northern Apennine. Transactions, Japanese Geomorphological Union 20-3, pp. 219-249.

Chedia, O. K. (1986) : Morphostructures and Neotectonic of the Tien Shan. Frunze, Ilim Publishing House, 314 pp. (in Russian).

Costa, J. E., Schuster, R. L. (1991) : Documented historical landslide dams from around the world. United States Geological Survey Open-File Report 91 - 239, 486p.

Fedorenko, V. S. (1988) : Rockslides and rockfalls, there prediction. Moscow State University publishers, 211 pp. (in Russian).

Ermini, L., Casagli, N. (2003) : Prediction of the behavior of landslide dams using a geomorphological dimensionless index, Earth Surface Processes and Landforms Vol. 28, pp. 31-47.

Ermini, L., Casagli, N., Farina, P. (2006) : Landslide dams : analysis of case histories and new perspectives from the application of remote sensing monitoring techniques to hazard and risk assessment. Italian Journal of Engineering Geology and Environment, Special Issue 1, pp. $45-52$.

Gaziev, E. (1984) : Study of the Usoi Landslide in Pamir. In Proc. 4th Int. Symp. on Landslides, Toronto, Vol. 1, pp. 511-515.

Gerasimov, V. (1965) : The Issyk catastrophe in 1963 and its ef- 
fects on geomorphology of the Issyk River Valley. Transactions of the All-union Geographic Society. Vol. 97, issue 6, pp. 541-547 (in Russian).

Hartvich, F., Mugnai, F., Proietti, C., Smolkova, V., Strom, A. (2008) : A reconstruction of a former rockslide-dammed lake: the case of the Kokomeren River valley (Tien Shan, Kyrgyzstan). Poster presentation at the EGU conference, Vien.

Hewitt, K. (2006) : Disturbance regime landscapes: mountain drainage systems interrupted by large rockslides. Progress in Physical Geography, Vol. 30, 3, pp. 365-393.

Ignatiev, I. V. (1886) : The earthquake in the Tokmak district in the 1885. Proceedings of the Russian Imperial Geographic Society, 22, Issue 2. (in Russian).

Ischuk, A. R. (2006) : Usoi natural dam: problem of security (Lake Sarez, Pamir Mountains, Tadjikistan) Italian Journal of Engineering Geology and Environment, Special Issue 1, pp. $189-192$.

Kazakov, Yu. M. : Lake Sarez. The Usoi blockage and Rightbank slope. Some results of engineering-geological studies performed in 1981-1992. (in Russian) http://sarez.ferghana.ru/kazakov.html

Korup, O. (2004) : Geomorphometric characteristics of New Zealand landslide dams. Engineering Geology, Vol. 73, pp. 13-35.

Korup, O., Strom, A. L., Weidinger, J. T. (2006) : Fluvial response to large rock-slope failures-examples from the Himalayas, the Tien Shan, and the Southern Alps in New Zealand. Geomorphology, Vol. 78, pp. 3-21.

Korup, O., Clague, J. J., Hermanns, R. L., Hewitt, K., Strom, A. L., Weidinger, J. T. (2007) : Giant landslides, topography, and erosion. Earth and Planetary Science Letters Vol. 261, pp. $578-589$.

Makarov V. I. (1977) : Newest tectonic structure of the Central Tien Shan. Science publishers, Moscow, 172 pp. (in Russian).

Mamyrov, E. M., Korjenkov, A. M., Strom, A. L., et al. (2009) : Geodynamics of the Talas-Fergana fault in the Tien Shan and Natural disasters of the Central Asia. Bishkek, Arashan Publishers, 228 pp. (in Russian).

Neshikhovskiy, R. A. (1988) : Floods on rivers and lakes. Leningrad, Hydrometeoizdat. 184 pp. (in Russian).

Papirin, L. P. (1990) : Main regularities of water seepage through the Usoi blockage. TajikNIINTI, Dushanbe, pp. 6 11. (in Russian).

Paramonov B. A. (1969) : Formation of the Usoi blockage relief. Herald of Moscow State University, No 5, pp. 110-112. (in Russian).

Preobrajensky, I. A. (1920) : The Usoi Landslide. Geol. Comm., Papers on Applied Geol., Vol. 14, pp. 21. (in Russian).

Pushkarenko, V. P., Nikitin A. M. (1988) : Experience in the Regional Investigation of the State of Mountain Lake Dams in Central Asia and the Character of Breach Mudflow Formation. Landslides and Mudflows (in two volumes). UNESCO/ UNEP. Moscow. (in Russian)

Reizvikh, V. N., Krukovskiy, G. L., Nikitin, A. M. (1971) : Causes and conditions of the Yashinkul Lake outburst. Collection of papers of the Tashkent Hydro-Meteorological Observatory, Issue 4, pp. 49-95. (in Russian).

Rezvoi, D. P., Rezvoi, P. D. (1969) : Lake that disappeared. Priroda (Nature), No 7, pp. 81-83. (in Russian).

Rezvoi, D. P., Alexeenko, A. V., Bolgar, B. D., Ermolenko, Yu. A., Marushkin, I. A., Rezvoi, P. D., Soloshenko, I. I. (1971) : Rockfall-dammed lakes of the Alai Range-important factor of the high mountain relief formation. Reports and News of the L'vov branch of the Ukraine Geographical Society (1968 -1969). L'vov University Publishing House, pp. 71-73. (in Russian).
Scheko, A. I., Lekhatinov, A. M. (1970) : Current state of the Usoi Blockage and tasks of future studies. In Materials of Scientific-technical meeting on the problems of study and forecast of the mudflows, rockfalls and landslides, Dushanbe, pp. 219-223. (in Russian).

Schuster, R. L. (2002) : Usoi landslide dam, southeastern Tajikistan. In Proc. Int. Symp. on Landslide Risk Mitigation and Protection of Cultural and Natural Heritage, Kyoto, pp. 489505.

Shpilko, G. A. (1915) : New data on the Usoi blockage and the Sarez Lake. In: Proc. of the Turkestan Department of Russian Geographical Society, 11, pp. 11-17. (in Russian).

State Water Inventory (1986-1988): Annual and Long-Term data on the state and resources of the on-land superficial waters. Vol. V, issue 4-Southern Kazakhstan, Vol. XI-Kyrgyzstan, Vol. XII-Tajikistan. Obninsk, VNIIGMI-World Data Center. (in Russian).

Strom, A. L. (1994) : Mechanism of stratification and abnormal crushing of rockslide deposits, in Proc. 7th International IAEG Congress 3, Rotterdam, Balkema, pp. 1287-1295.

Strom, A. L. (1996) : Some morphological types of long-runout rockslides: effect of the relief on their mechanism and on the rockslide deposits distribution. In: K. Senneset (Ed.) Landslides. Proc. of the Seventh International Symposium on Landslides, 1996, Trondheim, Norway, Rotterdam, Balkema, pp. $1977-1982$.

Strom, A. L. (1998) : Giant ancient rockslides and rock avalanches in the Tien Shan Mountains, Kyrgyzstan, Landslide News, No 11, pp. $20-23$.

Strom, A. L. (2006) : Morphology and internal structure of rockslides and rock avalanches: grounds and constraints for their modelling. In: Evans, S.G., Scarascia Mugnozza, G., Strom, A., Hermanns, R. L. (Eds.) Landslides from Massive Rock Slope Failure. NATO Science Series: IV : Earth and Environmental Sciences, Vol. 49, pp. 305-328.

Strom, A. L. (2010) : Evidence of momentum transfer during large-scale rockslides' motion. In: Williams, A. L., Pinches, G. M., Chin, C. Y., McMorran, T. G., Massei, C. I. (Eds.) Geologically Active, Proc. of the 11th IAEG Congress, Aickland, New Zealand, 5-10 September 2010, Tailor \& Frensis Group, London, pp. $73-86$.

Strom, A. L., Abdrakhmatov, K. E. (2004) : Clustering of large rockslides: the phenomenon and its possible causes. In: Lacerda,W. A., Ehrlich, M., Fontoura, A. B., Sayao, A. (Eds.), Landslides: Evaluation and Stabilization. Taylor and Francis Group, London, pp. $317-320$.

Strom, A. L., Abdrakhmatov K. E. (2009) : Rockslides and Rock Avalanches of the Kokomeren River Basin (Central Tien Shan). ICL Summer School on Rockslides and Related Phenomena Guidebook. 99pp. http : //www.iclhq.org/

Strom, A. L., Korup, O. (2005) : Extremely large rockslides and rock avalanches in the Tien Shan Mountains, Kyrgyzstan. Landslides, 3, pp. $125-136$.

Strom, A. L., Stepanchikova P. (2008) : Seismic triggering of large prehistoric rockslides: Pro and Con case studies. Proceedings of the International Conference on Management of Landslide Hazard in the Asia-Pacific Region (Satellite symposium of the First World Landslide Forum, Tokyo), Sendai, 11th - 12th November 2008, pp. 202-211.

UN International Strategy for Disaster Reduction (2000) : Usoi Landslide Dam and Lake Sarez. An Assessment of Hazard and Risk in the Pamir Mountains, Tajikistan. ISDR Prevention Series, No1. UN, New York and Geneva, 115pp.

Yi, C., Zhu, L., Seong, Y.B., Owen, L.A., Finkel, R. C. (2006) : A late glacial rock avalanche event, Tianchi Lake, Tien Shan, Xinjiang. Quaternary International. Vol. 154-155, pp. 26-31. (Received April 24, 2010, Accepted September 27, 2010) 